\title{
Annotated list of Finnish crane flies (Diptera: Tipulidae, Limoniidae, Pediciidae, Cylindrotomidae)
}

\author{
Jukka Salmela
}

\begin{abstract}
Salmela, J. 2011: Annotated list of Finnish crane flies (Diptera: Tipulidae, Limoniidae, Pediciidae, Cylindrotomidae). — Entomol. Fennica 22: 219-242.

A list of Finnish crane fly species is presented (Diptera: Tipuloidea). A total of 331 species are recorded from Finland and presented in a table (Limoniidae 192 spp., Tipulidae 113 spp., Pediciidae 19 spp. and Cylindrotomidae 7 spp.). Twenty-four species are formally reported for the first time from Finland (23 Limoniidae, 1 Tipulidae). Twenty-two species that were previously reported are deleted from the Finnish list (11 Limoniidae, 11 Tipulidae). Locality data, including the occurrence of species within Finnish biogeographical provinces, was available for all but one species. The southern provinces Ta (229 spp.), Ab (226 spp.) and N (203 spp.) are the most species rich; fewer species are found in the northernmost provinces (Le 128, Li 135 spp.). Ten species occur in all 21 provinces whereas 27 species are recorded only from a single province so far. A short review of the history of crane fly research in Finland is provided.
\end{abstract}

\section{J. Salmela, Department of Biology, Zoological Museum, FI-20014 University of Turku, Finland; E-mail: jueesal@utu.fi}

Received 16 May 2011, accepted 19 September 2011

\section{Introduction}

Crane flies are small to large sized, slender nematoceran flies (Fig. 1). Most species are characterized by long legs that easily drop off from dry and fresh specimens. Crane flies have been very often divided into three families or subfamilies. Starý (1992) elevated the pediciines to family status and now many workers recognize four families: Cylindrotomidae, Limoniidae, Pediciidae and Tipulidae. The phylogeny of crane flies has, however, proven difficult, and according to a recent analysis based on morphology (adults and immature stages) and molecular data, only Pediciidae and Tipulidae are held to be families (Petersen et al. 2010). Limoniidae is apparently not a natural group and belongs within the Tipulidae which consists of several subfamilies. Due to the limited number of genera (44) and species (45) used by
Petersen et al. (2010), several genera within traditional Limoniidae remain unplaced, hence, complete and consistent crane fly classification is still to be constructed and four families are recognized here.

Crane flies are very speciose and ecologically diverse. Over 15,000 species have been described (Oosterbroek 2011) and apparently a large number of species are yet to be recovered by taxonomists (de Jong et al. 2008). Most crane flies prefer moist environments. Crane fly species may be encountered from truly aquatic habitats to moist soils, and anything in between (e.g. Alexander 1920, Brindle 1967). Some species are, however, restricted to dry environments, e.g. members of the desert-dwelling subgenus Tipula (Eremotipula) (Gelhaus 2005). Most crane fly larvae eat detritus or prey upon other invertebrates (Alexander 1920). Some species are saproxylic, some in- 


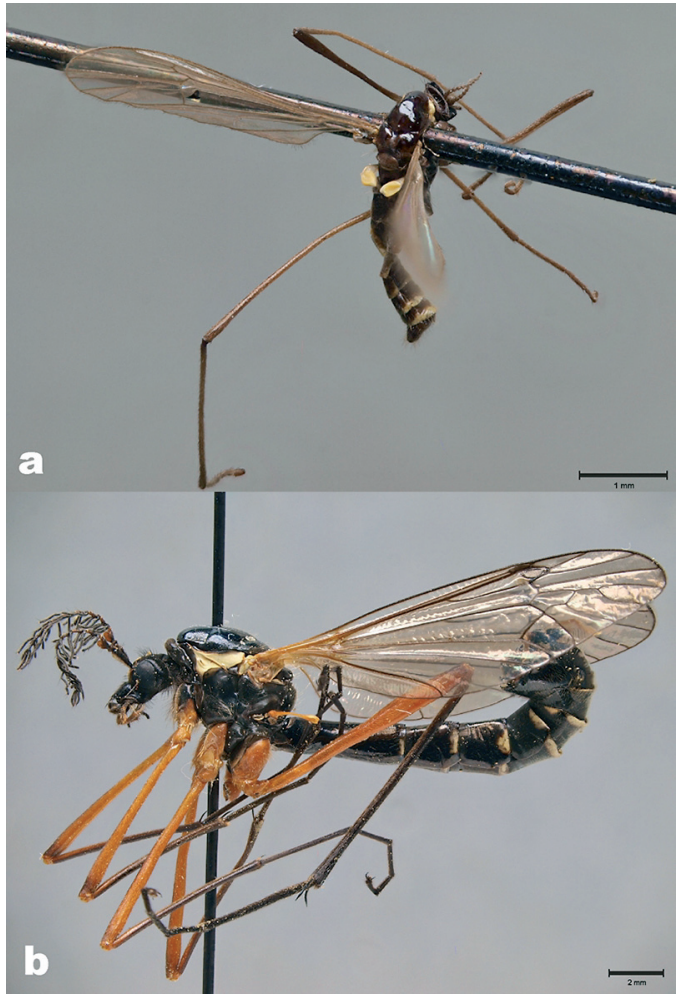

Fig. 1. - a. Symplecta lindrothi (Tjeder, 1955). Adult male, habitus photo. Finland, Ab: Karjalohja, R. Frey leg. $(\mathrm{MZH})$. This specimen was identified by Lundström (1912) as Symplecta meigeni (Zetterstedt). Symplecta lindrothi is so far only known from Finland and Sweden. - b. Ctenophora guttata Meigen, 1818. Adult male, habitus photo. Finland, Ab: Lohja, J. Kahanpää leg. 2005 (ZMUT).

fest fruiting bodies of fungi (Alexander 1920, Brindle 1967) and cylindrotomid larvae are herbivorous, feeding on mosses or higher plants (Peus 1952). Adults have non-biting mouthparts but they may suck plant nectar or other liquids (Alexander 1920). Crane flies may occur abundantly in the boreal and arctic biomes (Chernov \& Lantsov 1992) thus comprising an important component of food-webs (e.g. MacLean 1973). The majority of crane flies are "harmless" and inconspicuous. Only larvae of Tipula (Tipula) spp. and Nephrotoma spp. are known to cause economic loss in pastures or cultivated fields (Oosterbroek 1978, Blackshaw \& Coll 1999).

This article presents an annotated check-list of crane fly species and their occurrence in the Finnish biogeographical provinces. In addition, a succinct review of the history of crane fly research in Finland is provided.

\section{Material and methods}

This article is an update of a privately published account of Finnish semiaquatic flies, including crane flies, non-peer-reviewed and written in Finnish (Salmela 2006). Most of the corrections to this list of Finnish crane flies were mentioned by Salmela (2006), and they were also communicated to Pjotr Oosterbroek and have been incorporated into the Catalogue of the Craneflies of the World (Oosterbroek 2011). In addition, some species have been reported as new for the regional fauna in unpublished MSc theses (Salmela 2005, Autio 2008, Nieminen 2008, Lehkonen 2009). The aim of this article is to make these faunistic records more readily available to a wider audience, including persons and institutions that track changes in the national species lists (e.g. Silfverberg 1986, 1996).

Crane fly species were accepted to the Finnish list if documented museum specimen(s) exist in native or foreign collections. An exception was made for Tipula peliostigma for which there was relevant literature but no specimen could be traced (see below for details). Several species that had been listed as Finnish were omitted because the collecting localities were not part of the modern, post World-War II boundaries of Finland, or the inclusion of the species had been erroneous for other reasons. In addition to the species that are added or removed from the Finnish list, locality data for five other noteworthy or poorly known crane flies are given.

It is traditional to map Finnish species using the 21 biogeographical provinces (Fig. 2a) (see e.g. Lahti et al. 1988, Väisänen et al. 1992). Data on the occurrence of tipuloids in these provinces was extracted from the database of Finnish crane flies (created and updated by J. Salmela). This non-public database was formed in 2006 (Salmela 2006) and includes data from Finnish museum specimens (MZH, ZMUT, FOR, ZMUO), private collections, publications and unpublished investigations of field samples from Finland.

If not otherwise stated, specimens of species recognized as new for Finland are deposited in the Zoological Museum, University of Turku, 
Fig. 2. - a. Finnish biogeographical provinces. -b. Finnish ecoregions or vegetation zones $(1=$ hemiboreal, 2 = southern boreal, $3=$ middle boreal, $4=$ northern boreal).

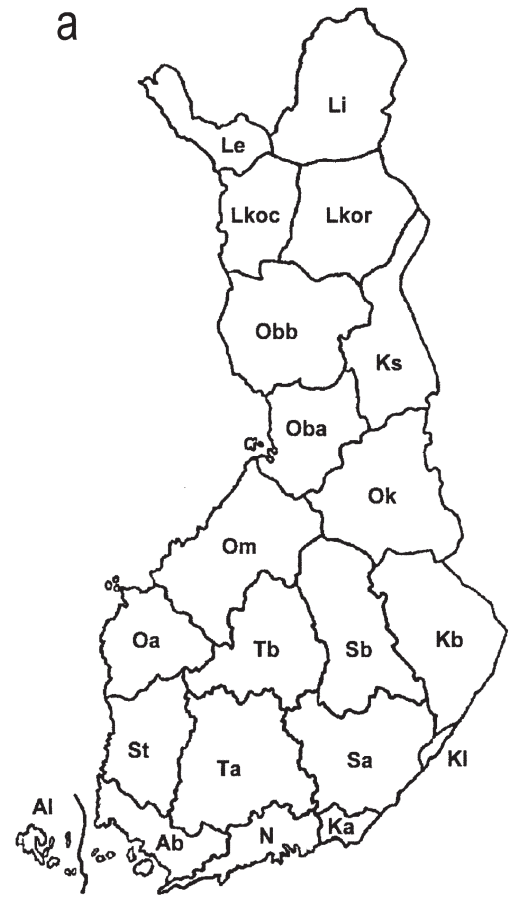

Finland (ZMUT). Acronyms for other museums or private collections are: MZH (Finnish Museum of Natural History, University of Helsinki, Finland); PMO (private collection of Pekka Majuri, Oulu, Finland); OAJ (private collection of Olli Autio, Jyväskylä, Finland); PRAS (Forest Research Institute, Karelian Research Centre of Russian Academy of Sciences, Petrozavodsk, Russia); FOR (Forssa Museum of Natural History, Finland); ZMUO (Zoological Museum, University of Oulu, Finland). Nomenclature follows Oosterbroek (2011). Species are arranged in the four family classification as mentioned above, and in alphabetical order within families. Abbreviations ex. (1 specimen) and exx. (two or more specimens) refer to number of specimens when sex of the specimen(s) is not reported. More accurate locality data is available in the database.

\section{History of crane fly research in Finland}

The first publication of Finnish crane flies comes from the $18^{\text {th }}$ century. Pharmacist Johan Julin from Oulu lists 19 tipulid species (Julin 1792). Collections of Julin were destroyed by fire and

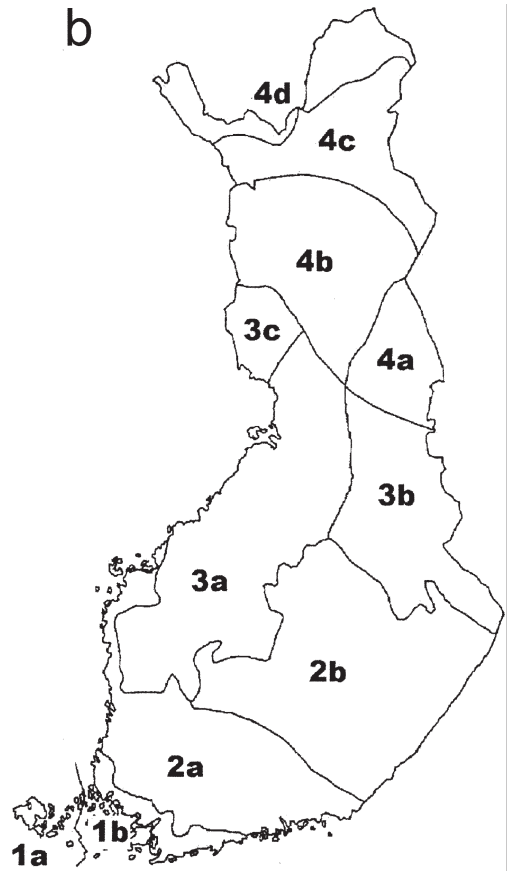

his crane fly records are unavailable, therefore, this publication has historical value only.

Professor Carl Lundström, Doctor of Medicine, was the first who studied Finnish crane flies seriously. In his youth, Lundström studied zoology and, among other things, he made a profitable entomological trip to North Savo with J. A. Palmén in 1865 (Frey 1915). Lundström focused his professional attention on medicine but at age 60 , at the time of his retirement, he returned to entomology and published four important papers (Lundström 1907a, 1907b, 1912, Lundström \& Frey 1916). The last one was co-authored with R. Frey and published after his death. These articles formed the basis for Finnish crane fly taxonomy and faunistics. Lundström described several new species, many of these are still valid (e.g. Cheilotrichia areolata, Dicranomyia patens, Tipula bistilata, T. cinereocincta). His illustrations were rather good (e.g., Dicranomyia magnicauda, Fig. 3).

Ernst Evald Bergroth, a physician, was a Finnish entomologist who mainly studied Hemiptera. Bergroth was not a field naturalist; he mainly studied specimens collected by others and he was well aware of the taxonomic literature, even outside his own field of speciality (Lindberg 1927 


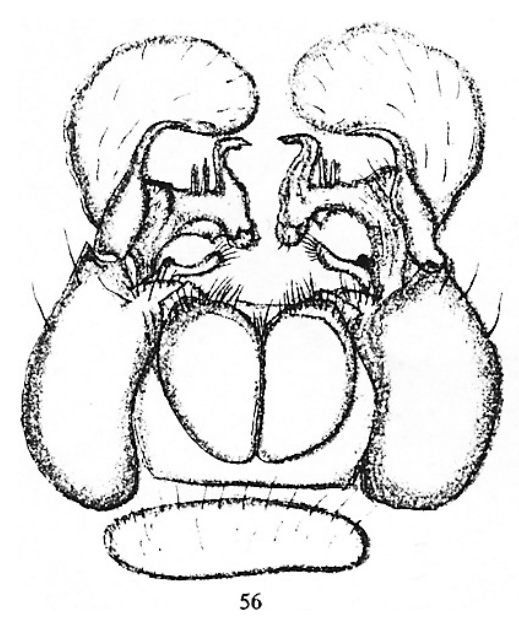

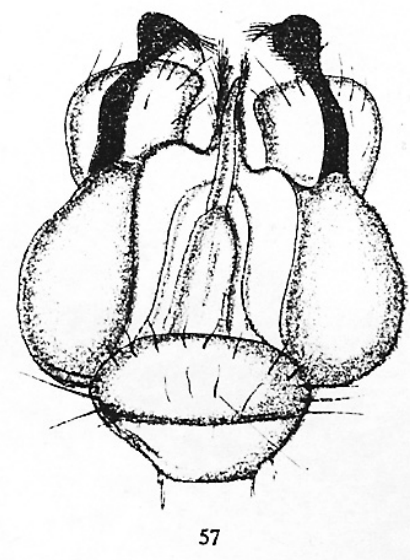

Fig. 3. Illustration of a limoniid male hypopygium by Carl Lundström (Lundström 1912, Plate 4, figures 5657, Dicranomyia (Idiopyga) magnicauda). Left: dorsal view; right: ventral view.
1928). Species of crane flies described by Bergroth were not from Finland, but from North America, Central Europe and South Africa (e.g. Bergroth 1888a,b,c,d). Some of his holotypes and lectotypes (e.g. Tipula (Mediotipula) bidens and Tricyphona contraria) are deposited in MZH.

Between the 1920's and 40's there was no Finnish entomologist devoted to the study of crane flies. Richard Frey, who made a long professional career studying other dipteran families, described one pediciid from Kola Peninsula, Russia (Frey 1921) and Frey with his co-authors recorded crane flies from Finland (Frey et al. 1941). Rolf Krogerus collected Fennoscandian miredwelling arthropods, including crane flies, in 1930's to the 50's (Krogerus 1960). Probably Krogerus did not identify the bulk of crane flies from these samples, although he described two tipuloids from North Finland and one of these, Phylidorea umbrarum, is still valid (Krogerus 1937). In his short note reporting crane flies new for Finland, Krogerus (1936) remarked that Ragnar Storå had identified the crane flies from the mires. We do not know how well Storå knew crane fly taxonomy because, besides the above mentioned enumeration (Frey et al. 1941), Storå did not publish anything on crane flies. Latvian Paul Lackschewitz was one of the most important foreigners to examine the crane fly collection deposited in the Zoological Museum, University of Helsinki (now MZH) (see Frey 1932, 1934, Lackschewitz 1924, 1936). The German, Max Riedel, and the Dane, Peder Nielsen, also identified specimens from this collection (e.g. Nielsen
1929). In the 1930's a small taxonomic paper on Finnish snow crane flies (Chionea, Limoniidae) was published by Eino Tahvonen (1932), but both his species were later synonymised (Oosterbroek \& Reusch 2008).

Another very prominent taxonomist who studied Finnish crane flies was Bernhard Mannheims from Germany. His publications gathered together the faunistic information, known at that time (e.g. Mannheims 1954, 1963a, 1963b, 1964a, 1965a). Of the Finnish species described by him, Tipula (Pterelachisus) kaisilai and Tipula (Yamatotipula) fendleri are still valid; the latter only recorded from Finland. Torild Brander, an enthusiastic nature conservationist and naturalist, and a very influential person in southwest Häme, organized insect collecting, including crane flies, in the municipalities such as Urjala, Forssa, Ypäjä and Somero. This material was sent to Mannheims for identification (see e.g. Mannheims 1965b, Brander 1964). Most of the crane fly species collected from SW Häme are deposited in the Natural History Museum of Forssa, most surplus specimens were donated to MZH. The Swede, Bo Tjeder, studied the MZH collection in 1950's and 60 's, and among other things, he selected lectotypes and paralectotypes from Lundström's type series and he also published some high quality redescriptions (Tjeder 1963, 1965, 1969).

After the era of Mannheims and Tjeder there was a rather quiet period in the scientific study of Finnish crane flies. Swarming behavior of Erioptera flavata (as E. gemina) was studied by Savolainen \& Syrjämäki (1971). In his study of 
the Baltic coastal tipulids, Theowald (1982) identified several specimens trapped in Finland. Mendl et al. (1977) mapped the occurrence of Chionea species in northern Finland and Sweden and Itämies and Lindgren (1985) published a short paper dealing with the winter activity of Chionea. Walter Hackman (1980) listed Finnish Nematocera and amateur entomologist, Olavi Rautio, (known as O. Siitonen before 1985) reported several crane fly species new for the Finnish fauna (e.g. Rautio 1985, 1987) and he compiled a list of species from Inari Lapland (Siitonen 1984). Then Juhani Viramo (1992), based on the identifications of Rautio and the collections in $\mathrm{MZH}$, listed the species from northeast Finland (biogeographical province of $\mathrm{Ks}$ ). In her revision of the genus Prionocera, Canadian Fenja Brodo (1987) examined the relevant specimens deposited in $\mathrm{MZH}$, and re-identified all Finnish specimens of the subgenus Tipula (Tipula) (Brodo 1994). Russian Alexei Polevoi (2001) studied crane flies that were collected from old-growth forests of Ilomantsi in eastern Finland, including Elephantomyia krivosheinae, a limoniid new for Finland.

I have studied the ecology, faunistics, red-list status and taxonomy of Finnish crane flies in 2000's, and consequently dozens of species have been added to the Finnish fauna, and our knowledge of habitat associations and the extent of species' occurrence has much improved. Crane fly assemblages of various wetlands (open mires, springs and headwater streams) have been studied on a wide spatial scale (e.g. Salmela 2001, 2004, 2008, 2011, Salmela \& Ilmonen 2005, Autio \& Salmela 2010, Salmela et al. 2007). The holotype and most of the paratypes of Metalimnobia charlesi (Salmela \& Starý 2008) were collected from Finland and the status of species such as Cylindrotoma borealis and Tipula chonsaniana were re-evaluated (Salmela \& Autio 2007, 2009). The Red-list status of Finnish species was assessed for the first time (Penttinen et al. 2010). Finnish crane fly specimens have been included in taxonomic treatises (Starý 2004, 2007, Starý \& Salmela 2004, Starý \& Brodo 2009). A notable achievement has been the creation and maintenance of a tipuloid database (Salmela 2006) that currently consists of 14627 entries for 330 species.

\section{Crane fly fauna of Finland}

\subsection{Additions}

Limoniidae

Antocha (Antocha) vitripennis (Meigen, 1830)

Sa: Leivonmäki, Rutajoki, 2006, P. Majuri leg. and det., 19 larvae (PMO); Ok: Puolanka, Kuorejoki, 12.VII.2007, Kainuun ympäristökeskus leg., P. Majuri det., 1 larva (PMO); Obb: Rovaniemi, Ounasjoki, Tapionkylä, 20.IX.2006, Paksuniemi et al. leg., P. Majuri det., 1 larva (PMO); Li: Inari, Inarijoki, 17.IX.2008, Lapin ympäristökeskus leg., P. Majuri det., 1 larva (PMO).

Comments: This species is known only from larvae collected in bottom samples from riffles of streams and rivers. Thus, no adults of this species are so far recorded from Finland. Wide distribution in Europe (Oosterbroek 2011).

Austrolimnophila (Archilimnophila) harperi (Alexander, 1926)

Ks: Kuusamo, Kalliojoki, 2005, J. Salmela leg., 3 exx.; Ks: Kuusamo, Uopajanpuro, 2005, J. Salmela leg., 1 ex.; Ks: Kuusamo, Vuosseli, 2005, J. Salmela leg., 1 ex.; Ks: Taivalkoski, Mäntymaanoja, 2006, J. Salmela leg., 1 ex.; Oba: Pudasjärvi, Myllyoja (Vattukuru), 2006, J. Salmela leg., 1 ex.; Li: Utsjoki, Ruostepuro, 2006, P. Bagge leg., 6 exx.; Lkoc: Kittilä, Ylläs, 2006, J. Jakovlev \& J. Penttinen leg., 1 ex.; Le: Enontekiö, Tarvantovaara, Pahtavaara SE, 2009, J. Salmela leg., 1 ex.

Comments: The species is recorded only from the northern boreal ecoregion (see Fig. $2 b$ for the delineation of ecoregions). Collecting localities are headwater streams with rich riparian vegetation but so far it has not been recorded from treeless fell districts. Listed by Salmela (2006) from Ks and from Le: Tarvantovaara (Salmela 2011), but not with detailed locality data. Holarctic species, in Europe only known from Sweden and Finland (Oosterbroek 2011).

Dicranomyia (Dicranomyia) radegasti Starý, 1993

N: Espoo, Pitkäsuon laskupuro, 4.VII.2005, J. Ilmonen leg., 1 ऽ. 
Comments: The Finnish locality of this species is an intermittent headwater stream surrounded by herb-rich mixed forest. Reported by Salmela (2006) and by Autio (2008) from N. Known only from Finland, Slovakia and Czech Republic (Oosterbroek 2011).

Dicranomyia (Dicranomyia) zernyi Lackschewitz, 1928

Ok: Sotkamo, 31.VII.2006, L. Paasivirta leg., 1 §̊; Sb: Kiuruvesi, Jynkänjärvi 13.VII.2008 J. Salmela leg., 1 đ̊; Tb: Laukaa, Lähdesuo, 2008 J. Salmela leg., 1 đं; Kb: Lieksa, Kumpulaislampi

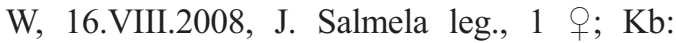

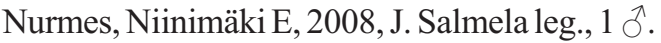

Comments: This species is collected from central and eastern Finland. Localities are characterized by lotic water (headwater streams, ditches with bare substrates) or by seeping groundwater (spring fen). Listed by Lehkonen (2008) in her MSc thesis, but without locality data. In Europe, perhaps boreo-montane species, known from Fennoscandia and Central Europe. Known also from eastern Palaearctic part of Russia (Oosterbroek 2011).

Dicranomyia (Glochina) liberta Osten Sacken, 1860

Ta: Lahti, Pekanmäki, 14.VII.2001, J. Salmela leg., 1 đ̊; N: Askola, 29.VIII.1999, A. Karhu leg., 1 §̊; Tb: Jyväskylä,Vaajakoski VI-VIII. 2004, L. Paasivirta leg., 3 exx.; Tb: Jyväskylä, Vesanka-Nyrölä, 9.VII.2004, L. Paasivirta leg., 3 exx.; Tb: Viitasaari, Heinäsuvanto, 30.VI.2004, L. Paasivirta leg., 1 §ं; Ok: Sotkamo, 31.VII. 2006, L. Paasivirta leg., 3 exx.

Comments: D. liberta is collected from central and eastern Finland, localities are swampy forests. Reported by Salmela (2006) from Ta and $\mathrm{Tb}$. The species is apparently a common crane fly in the Nearctic region (e.g. Young \& Gelhaus 2000). In the Palaearctic D. liberta is known from Russia, Mongolia and Finland (Oosterbroek 2011).

Dicranomyia (Idiopyga) intricata Alexander, 1927

Oba: Oulunsalo, Papinkari, 2005, T. Nieminen leg., 1 ex.; Oba: Oulunsalo, Välitörmä N, 2005, T. Nieminen leg., 1ex.; Oba: Hailuoto,
Pökönnokka, 2005, T. Nieminen leg., 3 exx.; Oba: Hailuoto, Kaaranselkä S, 2005, T. Nieminen leg., 1 ex.; Lkor: Kemijärvi, Salmiaavanhete, 15.VIII.2009, J. Salmela leg., 4 exx.; Lkor: Kemijärvi, Tunturilampi W, 15.VIII.2009, J. Salmela leg., 2 exx.; Lkor: Sodankylä, YläPostojoki, 2009, J. Salmela leg., 1 ex.; Lkoc: Kittilä, Mustaoja W, 19.VIII.2009, J. Salmela leg., 1 ex.; Lkoc: Kittilä, Merkkisenvuoma, 14.VIII.2009, J. Salmela leg., 1 ex.; Le: Enontekiö, Guhkesgielas N, 2009, J. Salmela leg., 1 ex.; Le: Enontekiö, Ravaltojärvi, 2009, J. Salmela leg., 1 ex.; Le: Enontekiö, Hietakero, 2009, J. Salmela leg., 1 ex.; Le: Enontekiö, Tomuttirova I, 2009, J. Salmela leg., 30 exx.; Le: Enontekiö, Tomuttirova II, 2009, J. Salmela leg., 57 exx.

Comments: This species has, apparently, rather disjunct distribution in Finland; it has been recorded from the northern Baltic and from the northern boreal ecoregion. However, the absence of the species between these two areas may be an artifact due to insufficient sampling. In the northern Baltic, D. intricata is collected from coastal meadows. In the northern boreal ecoregion, the species is mainly recorded from minerotrophic fens and less often from shores of streams and rivers. The species was reported by Salmela (2006) and by Nieminen (2008) from Oba and by Salmela (2011) from Le: Tarvantovaara. Dicranomyia intricata is Holarctic species, known from Canada (Alexander 1927), Sweden (Nielsen 1953, Tjeder 1958) and Finland.

Dicranomyia (Idiopyga) esbeni Nielsen, 1940

Oba: Oulunsalo, Papinkari, 2005, T. Nieminen leg., 1 ex.; Oba: Oulunsalo, Välitörmä S, 2005, T. Nieminen leg., 8 exx.; Oba: Hailuoto, Pökönnokka S, 2005, T. Nieminen leg., 3 exx.; Oba: Hailuoto, Kaaranselkä N, 2005, T. Nieminen leg., 3 exx.; Oba: Hailuoto, Tömppä, 2005, T. Nieminen leg., 1 ex.

Comments: In his MSc thesis Nieminen (2008) reported Dicranomyia melleicauda complicata de Meijere, 1918 as new for Finland. This material, collected from the northern Baltic, was recently re-examined and reclassified as $D$. esbeni. The occurrence of D. esbeni and D. $m$. complicata in Fennoscandia are further discussed by Salmela (2010). Dicranomyia esbeni is very rare species, collected only from Denmark (Niel- 
sen 1940, type locality), Finland and Mongolia (Podenas \& Gelhaus 2001, as D. sineloba). In the Finnish red-data book (Penttinen et al. 2010) D. esbeni is erroneously listed as Dicranomyia melleicauda.

Dicranomyia (Idiopyga) murina (Zetterstedt, 1851)

Ks: Taivalkoski, Pitkävaaranaho, 2002, J. Ilmonen, L. Paasivirta \& J. Salmela leg., 1 ơ; Ks: Kuusamo, Kiutaköngäs, 23.IX.1966, P. Lehtinen leg., 1 đ̊; Lkor: Sodankylä, Kitinen, 2009, J. Salmela leg., 2 exx.; Li: Utsjoki, Kevo, Kutuniemi, 2000, S. Neuvonen leg., 1 ô.

Comments: In Finland the occurrence of this species is poorly known. The species has been collected from northern boreal ecoregion, most often encountered near sandy shores of rivers. The species was reported by Salmela (2006) from Ks. Known from Fennoscandia, Lithuania, eastern Palaearctic Russia and Canada (Oosterbroek 2011).

Dicranomyia (Melanolimonia) occidua Edwards, 1926

Kb: Eno, Grönvik leg., 1 § (MZH); Kb: Eno, Woldstedt leg., 1 ก (MZH); Oba: Hailuoto, Kaaranselkä S, 2005, T. Nieminen leg., 1 ex.; Oba: Hailuoto, Tömppä, 2005,T. Nieminen leg., 1 ex.; Ok: Puolanka, Paljakkaoja, 2006, J. Salmela leg., 2 exx.; Ok: Puolanka, Iso Vuorilampi N, 25.V.-23.VI.2007, J. Salmela leg., 1 ex.; Obb: Tervola, Keskipalo, 2004, J. Salmela leg., 3 exx.; Obb: Tervola, Ruuttulampi, 2004, J. Salmela leg., 4 exx.; Obb: Tervola, Hirviaapa, 2004, J. Salmela leg., 4 exx.; Ks: Kuusamo, Kalliojoki, 2005, J. Salmela leg., 1 ふै; Ks: Kuusamo, Merenoja, 2005, J. Salmela leg., 1 đ; Ks: Kuusamo, Matinjärvi, 2005, J. Salmela leg., 1 đ̇; Ks: Kuusamo, Rinteenlammit, 2005, J. Salmela leg., 1 đ̂; Ks: Salla, R. Frey leg., 2 exx. (MZH).

Comments: In Finland, D. occidua is known from the middle and northern boreal ecoregions and is absent north of the polar circle. The species seems to prefer calcareous areas; it has been collected from springs and headwater streams in areas characterized by basic rocks. In addition, $D$. occidua was collected from a coastal meadow in the northern Baltic. The species was reported from Obb by Salmela (2005) and from Kb, Obb and Ks by Salmela (2006). Known from Europe and Mongolia (Oosterbroek 2011).

Dicranophragma (Brachylimnophila) separatum (Walker, 1848)

Comments: Known from all Finnish biogeographic provinces and from over 160 localities; $D$. separatum is one of the commonest crane flies of Finland. Dicranophragma nemorale (Meigen, 1818) (=Neolimnomyia (Brachylimnophila) nemoralis) has not yet been recorded from Finland and is thus deleted from the list of Finnish crane flies. Dicranophragma separatum was redescribed and ranked as a valid species by Starý and Reusch (2009). The species was reported from Le: Tarvantovaara by Salmela (2011). All recent records of Neolimnomyia (Brachylimnophila) nemoralis from Finland (e.g. Salmela 2001, 2004, Salmela et al. 2007) actually refer to D. separatum.

\section{Erioptera (Erioptera) tordi Tjeder, 1973}

Sb: Pieksämäki, Hietisenpuro, 2008, J. Salmela leg. $\left(1 \delta^{\top}\right)$.

Comments: A very rare and poorly known species, recorded from Sweden (type locality, Tjeder 1973), Finland and Russian Far East (Oosterbroek 2011). Finnish locality was a 3-4 meters wide, slow flowing headwater stream with a sandy bottom. Erioptera tordi was reported by Lehkonen (2008) from Sb.

Gonempeda flava (Schummel, 1829)

Ab: Pohja, Fiskarsinjoki, 2007, A. Rinne leg., 10 .

The Finnish locality is a stream surrounded by broad-leaved trees. Recorded from many European countries but not so far from Russia (Oosterbroek 2011).

Gonomyia (Gonomyia) abscondita Lackschewitz, 1935

St: Oripää, Myllylampi, 24.VI.2004, L. Paasivirta leg., 1 đ̊; Ta: Vilppula, Elämänmäki, 2008, J. Salmela leg., 4 exx.; Tb: Laukaa, Lähdesuo, 2008, J. Salmela leg., 1 đે; N: Espoo, Koivulan lehtopuro, 2006, J. Ilmonen leg., 2 exx.; N: Espoo; Pitkäsuon laskupuro, 2006, J. Ilmonen leg., 1 đ̊; N: Espoo, Pitkäsuon laskupuro, 2007, J. Ilmonen leg., 8 exx.; N: Nurmijärvi, Kiljavan 
lähteikkö, 4.VII.-6.VIII.2007, J. Kahanpää leg., 3 exx.; Sb: Vieremä, Puolinpuro, 2008, J. Salmela leg., 1 ơ; Kb: Lieksa, Pieni Ruosmanjärvi SE, 2008, J. Salmela leg., 1 ग.

Comments: Previous identifications of $G$. lucidula de Meijere, 1920 on Finnish material have been erroneous (Salmela 2006, Autio 2008, Lehkonen 2008). Re-examination of this material is based on a revision of G. lucidula and allied species (Starý 2011). Gonomyia abscondita is collected from springs and headwater streams, rarely from intermittent streams. In addition to Finland, confirmed records of this species are from Austria, Bulgaria, Czech Republic, Germany, Great Britain, Italy, the Netherlands, Slovakia and Sweden (Starý 2011).

Helius (Helius) pallirostris Edwards, 1921 $1 \hat{\jmath}$.

Ab: Korppoo, Utö, 22.VI.2008, O. Autio leg.,

Comments: The only known locality of this species in Finland is in the SW archipelago. The specimen was collected from a swamp dominated by sedges and grasses. A widespread European species, recorded also from eastern Palaearctic region (e.g. Tajikistan, Turkmenistan) (Oosterbroek 2011).

\section{Limonia messaurea Mendl, 1971}

Ok: Kuhmo, Tulisuo-Varpusuo, 8.-24.VIII.

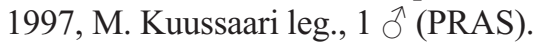

Comments: In terms of ecology and range size, a very poorly known species of which the nominotypical subspecies, L. messaurea $m$., is known from the type locality in North Sweden (Mendl 1971) and Finland, and the subspecies $L$. $m$. boreoorientalis Savchenko, 1987 is from Kamchatka, Russian Far East (Oosterbroek 2011). The Finnish locality is an old-growth forest. Reported by Salmela (2006) from Ok.

\section{Lipsothrix errans (Walker, 1848)}

N: Espoo, Pitkäsuon laskupuro, 2002, J. Ilmonen leg., 1 ऽ๋; N: Espoo, Pitkäsuon laskupuro, 2003, J. Ilmonen leg., 3 exx; N: Espoo, Koivulan lehtopuro, 4.VII.2005, J. Ilmonen leg., 2 exx.

Comments: Apparently a very rare species in Finland, known only from two neighboring sites in southernmost Finland. Localities are small and intermittent headwater streams surrounded by mixed forests. Reported by Salmela (2006) and Autio (2008) from N. Lipsothrix errans is a European species (Oosterbroek 2011).

Molophilus (Molophilus) occultus de Meijere, 1918

Ta: Somero, Hossojanlähteet, 2003, J. Ilmonen leg., 3 exx.

Comments: The species is recorded only from a single locality (mesotrophic or intermediate rich spring surrounded by pine mire) from southern Finland. Reported by Salmela (2006) from Ta. European species (Oosterbroek 2011).

Orimarga (Orimarga) juvenilis (Zetterstedt, 1851)

Obb: Tervola, Hirviaapa S, 28.VI.2.VIII.2004, J. Salmela leg., 1 §; Lkoc: Kittilä, Lomajärvenkuru, 1.VII.-2.VIII.2009, J. Salmela leg., 1 万.

Comments: Rare and most probably a northern species in Finland. Recorded from two calcareous rich fens. Reported by Salmela (2006) from Obb. European species (Oosterbroek 2011).

Ormosia (Oreophila) sootryeni (Lackschewitz, 1935)

N: Espoo, Pitkäsuon laskupuro, 4.VII.2005, J. Ilmonen leg., 1 female; N: Siuntio, Lempansån 10.VII.-2.VIII.2007, J. Kahanpää leg., 1 exx.; Ab: Vihti, Myllypuro, 2005, J. Ilmonen leg., 4 exx.; Ab: Pohja, Fiskars, Rislaå, 2007, A. Rinne leg., 1 ex; St: Kankaanpää, Kuninkaanlähde S, 2008, J. Salmela leg., 1 ex.; St: Kankaanpää, Lähdetneva, 2008, J. Salmela leg., 1 ex.; Oa: Kauhajoki, Kauhalammi SE, 2008, J. Salmela leg., 1 ex.; Sb: Vieremä, Puolinpuro1, 2008, J. Salmela leg., 2 exx.; Kb: Rautavaara, Pankapuro, 2008, J. Salmela leg., 1 ex.; Tb: Pihtipudas, Ilakanlähde, 2003, J. Penttinen leg., 1 ex.; Ks: Taivalkoski, Syväoja, 2006, J. Salmela leg., 1 ex.

Comments: $O$. sootryeni has been collected from hemiboreal to northern boreal ecoregions, but the species has not been recorded north of $66^{\circ} \mathrm{N}$ latitude in Finland. The species occurs in headwater streams, springs and herb-rich forests. Reported by Salmela (2006) from Ab, N and Tb and by Autio (2008) from Ab and N. The species was listed by Lehkonen (2008) and by Ilmonen 
and Salmela (2010) without explicit locality information. In Europe, it is only known from Fennoscandia; other records are from Russian Far East, Japan and North Korea (Oosterbroek 2011).

\section{Pilaria nigropunctata (Agrell, 1945)}

Ta: Ypäjä, 24.VI.1965, J. Kuusinen leg., 1 ๙ (FOR); Ta: Forssa, Koijärvi 21.VII.1964, M. Nokkala leg., 1 female (FOR); Ta: Somero, 6.VII.1964, J. Kuusinen, 1 female (FOR), Ta: Jokioinen, 13.VII.1964, J. Kuusinen leg., 1 female (FOR); Oa: Kuortane, 2007, L. Paasivirta leg., 1 male; Ab: Karjaa, Långån, 29.V.-10.VII. 2007, J. Kahanpää leg., 5 exx.; Ab: Pohja, Tomasbölebäcken, 29.V.-7.VII.2007, J. Kahanpää leg., 3 exx.

Comments: Most of the records of P. nigropunctata are from southern boreal or hemiboreal ecoregions, but only one of the records $(\mathrm{Oa})$ is from the middle boreal ecoregion. The species is collected around shores of lotic waters with luxuriant riparian vegetation. Specimens deposited in FOR were misidentified by Mannheims (1965b) as $P$. fuscipennis, the latter has not been recorded from Finland. Pilaria nigropunctata was reported by Salmela (2006) from Ta. European species, in addition to Finland known only from Czech Republic, Germany, Lithuania, Poland, Slovakia and Sweden (Oosterbroek 2011).

\section{Scleroprocta pentagonalis (Loew, 1873)}

Ok: Suomussalmi, Toskanoja, 2006, J. Salmela leg., 3 exx.; Ok: Paltamo, Pentinmäenpuro, 25.VI.-20.IX.2006, A. Rinne leg., 8 exx.; Ok: Paltamo, Vaarainjoki, 2007, A. Rinne leg., 3 exx.; Ok: Paltamo, Pentinsuonpuro, 2008, A. Rinne leg., 1 ex.; Oba: Pudasjärvi, Säynäjäoja, 2007, J. Salmela leg., 4 exx.

Comments: This species has been collected from calcareous districts at the boundaries of middle and northern boreal Finland. Localities are small headwater streams influenced by groundwater. Rather widespread European species, also recorded from Kazakhstan (Oosterbroek 2011, but see Starý 2008).

Symplecta (Psiloconopa) lindrothi (Tjeder, 1955)

Obb: Tervola, Keskipalo, 2004, J. Salmela leg., 1 q; Oba: Pudasjärvi, Salmioja, 2006, J. Salmela leg., 1 ex.; Oba: Pudasjärvi, Pelto-oja, 2006,
J. Salmela leg., 3 exx.; Li: Inari, Sarmitunturin erämaa, 18.VI.2001, J. Ilmonen leg., 1 ex.; Li: Inari, VI.2003, L. Paasivirta, 1 ex.; Tb: Jyväskylä, Woldstedt leg., 1 ○े (MZH); Oa: Nurmo, Jouttiluoma 4, 2008, O. Autio leg., 1 ते (OAJ); St: Karvia, Kantti, 3.V.-17.VI. 2010, J. Salmela \& T. Tuovinen leg., 1 ex.; Ab: Karjalohja, R. Frey leg., 1 ^ै (MZH).

Comments: A rather poorly known species collected from southern boreal to northern boreal ecoregions, but not from the subalpine zone. Localities are mainly small headwater streams. Reported by Salmela (2005) from Obb and by Salmela (2006) from Tb, Obb and Li. Only known from Finland and Sweden (Oosterbroek 2011).

Tasiocera (Dasymolophilus) fuscescens (Lackschewitz, 1940)

$\mathrm{N}$ : Espoo, Koivulan lehtopuro, 2002, J. Ilmonen leg., 3 exx.; same locality but 2003, 2 exx.; same locality but 2005, 5 exx.; same locality but 2006, 9 exx.; same locality but 2007, 13 exx.; $\mathrm{N}$ : Espoo, Pitkäsuon laskupuro, 2002, J. Ilmonen leg., 3 exx.; same locality but 2003, 2 exx.; same locality but 2005, 5 exx.; same locality but 2007 , 12 exx.; N: Espoo, Antiaanpuro, 2003, J. Ilmonen leg., 1 ex.; same locality but 2006, 1 ex.; same locality but 21.VI.-30.VII.2007, 2 exx.; N: Mäntsälä, Ohkolanjoki, 2007, J. Kahanpää leg., 2 exx.; Ab:Vihti, Myllypuro, 2003, J. Ilmonen leg., 1 ex.; same locality but 21.VI.-30.VII.2007, 2 exx.

Comments: This species is most likely confined to southernmost Finland. Apparently $T$. fuscescens has relatively persistent populations since it has been collected repeatedly in the same trapping sites in succeeding years. Collecting sites are headwater streams, both with permanent and intermittent water flow. The species was reported by Salmela (2006) and Autio (2008) from $\mathrm{Ab}$ and N. A European species according to Oosterbroek (2011).

Tipulidae

Ctenophora (Ctenophora) nigriceps (Tjeder, 1949)

Kb: Lieksa, Pieni Ruosmanjärvi SE, 19.V.22.VI.2008, J. Salmela leg., 1 ㅇ.

Comments: $C$. nigriceps is among the most 
poorly known and rarest members of Fennoscandian crane flies. The Finnish locality is a managed coniferous forest still having some characteristics of old-growth spruce forests (e.g. higher amount of decaying trees than in an average managed forest in southern Finland). The species is known from northern Sweden (Sandström 2008), Finland and Slovakia (Starý 2009). The larvae are most probably saproxylic (Oosterbroek et al. 2006).

\subsection{Deletions}

Limoniidae

Arctoconopa quadrivittata (Siebke, 1872)

Erroneously reported from Finland by Savchenko et al. (1992) and Reusch and Oosterbroek (1997).

Dicranomyia (Dicranomyia) chorea (Meigen, 1818)

This species was reported by Mannheims (1965b) from Urjala (Urjala, 12.IX.1963, T. Brander leg., 1 , FOR) and Forssa (Forssa, 24.VII.1963, E. Nylund leg., 1 क, FOR) (biogeographical province of Ta). Specimens identified as $D$. chorea by Mannheims are deposited in FOR and were examined by the author. Most likely these female specimens do not belong to $D$. chorea because their wing pattern is very different from $D$. chorea specimens collected from South Sweden (examined by the author in the Museum of Zoology, University of Lund, Sweden). Hence, the species is deleted from the list of Finnish crane flies.

\section{Dicranomyia (Dicranomyia) ornata (Meigen, 1818)}

Added to the Finnish list by Geiger (1986), based on literature records. However, it remains unclear which publication is behind this addition. I scanned trough all refenrences dealing with Finnish limoniids, and those mentioned by Geiger (1986, pp. 98-99), and found no indication on the presence of this species in Finland. Also reported from Finland by Savchenko et al. (1992) and Reusch and Oosterbroek (1997), based on Geiger's (1986) publication. Although a rather widespread European species, Dicranomyia ornata is not known from Sweden, Norway or Denmark (Oosterbroek 2011).

Dicranomyia (Glochina) schineriana (Alexander, 1964)

This has been a problematic species with confusing literature records. However, I conclude that $D$. schineriana has been erroneously interpreted as a Finnish species. First of all, $D$. schineri was described by Lackschewitz (1928), based on Central European material. Alexander (1964) proposed a new name $D$. schineriana for D. schineri, which was preoccupied. Dicranomyia schineriana was listed as a synomym of $D$. schineri by Savchenko et al. (1992), but the name D. schineriana was reinstated by Oosterbroek (2009). According to my knowledge, D. schineriana has never been collected from Finland. The main confusion has arisen since Hackman (1980) listed D. subtristis Alexander, 1924 from Finland and $D$. schineri as its synonym. In reality, $D$. subtristis is a junior synonym of $D$. tristis (Schummel, 1829). Silfverberg (1986) added $D$. schineriana to the Finnish list because it was considered by Geiger (1985) to be a distinct species from $D$. tristis. Hence, the addition of $D$. schineriana to the Finnish list was done due to the misconception in nomenclature between $D$. tristis and D. schineriana.

\section{Dicranophragma (Brachylimnophila) nemorale (Meigen, 1818)}

This species has not yet been found in Finland; earlier records (mostly as Neolimnomyia [Brachylimnophila] nemoralis) refer to $D$. separatum (see above).

Erioptera (Erioptera) fuscipennis Meigen, 1818

Erioptera fuscipennis was recorded from $\mathrm{N}$ (Fagervik, Esbo, Palmen leg.) and Ta (Forssa, Bergroth leg.) by Lundström (1907b) and from Lkem (=Lkoc, Muonio 28.VI and 2.VII 1911, Frey leg.) by Lundström (1912). However, all specimens except the unavailable $\widehat{\delta}$ from Forssa were re-examined by me (in MZH) and proved to belong to E. beckeri Kunze, 1914. Erioptera fuscipennis has not been recorded from Finland. 
Euphylidorea lineola (Meigen, 1804)

Euphylidorea lineola has been reported from Finland by Lundström (1912). Deleted from the Finnish list because specimens in MZH identified as E. lineola belong to Euphylidorea dispar (Meigen, 1818) or Phylidorea fulvonervosa (Schummel, 1829).

Hexatoma (Hexatoma) nubeculosa (Burmeister, 1829)

Lundström (1907b) reported this species from Petrozawodsk (Russia, J. Sahlberg leg.). There are four poorly labeled specimens that were probably seen by Lundström; only one specimen bears a small yellow label, "48". Specimens reported from Ks: Kuusamo (Viramo 1992) belong to H. fuscipennis (Curtis, 1836) (ZMUO).

\section{Idioptera macropteryx Tjeder, 1955}

This species has been lowered in its taxonomic rank and is now recognized as Idioptera pulchella (Meigen, 1830), var. macropteryx (see Starý 2007). Idioptera macropteryx was reported from Finland by several authors, e.g. Mannheims (1965b, 1972), Siitonen (1984) and Salmela (2001).

Ormosia (Ormosia) nodulosa (Macquart, 1826)

This species was reported by Krogerus (1960) from Finland ( $\mathrm{a}$ fen in $\mathrm{Kb}$ ) and was added to the Finnish list by Salmela (2006). There is, however, no specimen in MZH or other Finnish collections and there is no information about who identified this material. The specimen or specimens were collected in 1940's (Krogerus 1960) and perhaps identified in 1940's or 1950's. Due to the poor information and susceptibility of this finding, $O$. nodulosa is deleted from the list of Finnish crane flies.

Pilaria fuscipennis (Meigen, 1818)

Finnish specimens were misidentified by Mannheims (1965b); see above Pilaria nigropunctata.

Tipulidae

Prionocera dimidiata (Loew, 1866)

This species was reported from Finland by Rautio (1986, as P. absentiva Mannheims). The specimen was misidentified; it belongs to $P$. chosenicola Alexander, 1945 (ZMUO).

Tipula (Acutipula) luna Westhoff, 1879

This species has not been recorded within the modern (post World War II) boundaries of Finland (recorded from Terijoki, Karelian Isthmus [Mannheims, 1954]).

Tipula (Acutipula) vittata Meigen, 1804

This species was listed by Mannheims (1963b, 1965a, 1967a) from Finland, but I have found neither Finnish material of this species nor any more detailed literature record from Finland. Tipula vittata was not listed by Hackman (1980) from Finland.

Tipula (Lunatipula) livida van der Wulp, 1859

This species was added to the Finnish list by Mannheims (1954). The studied specimen (Tb:

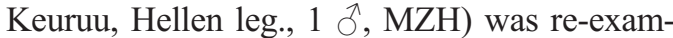
ined by me and found to be T. circumdata Siebke, 1863.

Tipula (Pterelachisus) middendorffi Lackschewitz, 1936

This species was marked as "SF?" by Oosterbroek \& Theowald (1992), indicating doubtful Finnish record. Mannheims (1963a) reported $T$. middendorffi new for the Norwegian fauna (specimen in MZH, Hellen leg.). Mannheims (1963a) hypothesizes the potential occurrence of this species in northern Finland and Sweden, but no specimens have hitherto been recorded from Finland.

Tipula (Pterelachisus) pauli Mannheims, 1964

This species was included by Mannheims (1967a) in the list of Finnish Tipulidae. This record has been rejected since neither Hackman (1980) nor Oosterbroek \& Theowald (1992) list this species from Finland. It is likely that the inclusion of T. pauli in the Finnish list is due to the nomenclatural confusion around Tipula hortulana (e.g. Lackschewitz 1932, Mannheims 1964b).

Tipula (Pterelachisus) pseudovariipennis Czizek, 1912

This species was reported as a new for Finland by Mannheims (1963a), based on records on 
two Finnish specimens. These identifications were accepted by Salmela (2009) in his account of the subgenus Tipula (Pterelachisus) in Finland. Specimens (Om, Jakobstad, R. Frey leg., 1 q, MZH; Ab, Pargas, Ingelius leg., 1 \%, FMHN) were re-identified by me in November 2010: female specimen from Jacobstad is not T. pseudovariipennis, but may belong to $T$. (P.) luridorostris Schummel, 1833 and the female specimen from Pargas belongs to $T$. (P.) varipennis Meigen, 1818.

Tipula (Savtshenkia) persignata tofina Alexander, 1945

This species was erroneously listed by Oosterbroek \& Theowald (1992) from Finland.

Tipula (Savtshenkia) postposita Riedel, 1919

This species was listed by Oosterbroek \& Theowald (1992) from Finland, but the species has not been recorded within Finnish boundaries (a specimen collected by Montell from Russia, Kola Peninsula is deposited in MZH, see also Mannheims (1963a), p. 38).

Tipula (Yamatotipula) fenestrella Theowald, 1980

This species has not been recorded within the modern (post World War II) boundaries of Finland (recorded from Metsäpirtti, Karelian Isthmus $[\mathrm{MZH}])$.

Tipula (Yamatotipula) pruinosa stackelbergi Alexander, 1934

Based on a revision of Tipula stackelbergi (Salmela 2012), this species does not occur in Europe and should be removed from the Finnish list.

\subsection{Other records: five poorly known species}

Limoniidae

Gnophomyia viridipennis (Gimmerthal, 1847)

N: Sipoo, Lilla Kummelberget, 3.VII.20.VIII.2007, J. Kahanpää leg., 1 ex; N: Sipoo, Rörstrand 16.VI.-15.VII.2008, E. Hyvärinen leg., 1 ex; N: Mäntsälä, Mustametsä, 2008, E. Hyvärinen leg., 1 ex; Ta: Lammi, Evo, Kotinen nature reserve, 2006, J. Jakovlev, J. Penttinen \&
G. Sthåls leg., 144 exx. reared from decaying aspen (Populus tremula) logs.

This species was reported for the first time from Finland (Åland Islands [Al]) by Hancock (2008). New records presented here are from the Finnish mainland, originating from old-growth forests.

Phylidorea (Macrolabina) nigronotata (Siebke, 1870)

Ta: Janakkala, Helvetinvuori, 8.VII.5.VIII.2008, T. Heinänen leg., 1 q; Ks: Salla, Aatsinkijoki, 13.VI. 2011, J. Ilmonen leg., 4 ठ̊.

Comments: This species was listed from Finland by Hackman (1980, as Limnophila (Euphylidorea) nigronotata) and later by Savchenko et al. (1992) and Reusch \& Oosterbroek (1997). However, before these recent findings, I had not seen any museum or other material from Finland, and the occurrence of this species was considered uncertain (Salmela 2006). The locality in Janakkala is a sun exposed, dry esker heath with vascular plants such as Antennaria dioica, Arctostaphyllos uva-ursi and Hypochoeris maculata. The locality in Salla is a river-bank meadow.

Rhabdomastix (Rhabdomastix) borealis Alexander, 1924

Li: Inari, Inarijoki, U. Sahlberg leg., 1 क (MZH), [det. as R. laeta by Lackschewitz]

This species was tentatively reported from Finland by Starý (2004). Lundström (1907b) gave a short diagnosis and a figure of a wing (as Gonomyia schistacea) that were interpreted by Starý to represent $R$. borealis. This female specimen from MZH was examined and its occurrence in Finland verified.

Tipulidae

Ctenophora (Ctenophora) pectinicornis (Linnaeus, 1758)

This species is only known from Åland Islands (biogeographical province of $\mathrm{Al}$ ). The single record from mainland Finland (Sb: Kuopio, Fabritius leg., P. Nielsen det. as pectinicornis, 1 female, $\mathrm{MZH}$ ) was a misidentification; the specimen belongs to $C$. guttata. There is a record of $C$. pectinicornis from Ab: Nauvo, Seili (O. Siitonen leg., ZMUO), but only a wing of this specimen is 
Table 1. Family specific and total numbers of crane fly species (Diptera: Limoniidae, Tipulidae, Pediciidae and Cylindrotomidae) and the number of singletons (i.e. species only known from one province) in the Finnish biogeographical provinces (see Fig. 2).

\begin{tabular}{lrrrrrr}
\hline Province & Limo. & Tipu. & Pedi. & Cyli. & All & Singl. \\
\hline $\mathrm{Al}$ & 66 & 44 & 3 & 3 & 116 & 1 \\
$\mathrm{Ab}$ & 135 & 70 & 15 & 6 & 226 & 3 \\
$\mathrm{~N}$ & 121 & 65 & 14 & 3 & 203 & 4 \\
$\mathrm{Ka}$ & 50 & 39 & 5 & 1 & 95 & 0 \\
$\mathrm{St}$ & 88 & 45 & 13 & 6 & 152 & 0 \\
$\mathrm{Ta}$ & 136 & 71 & 16 & 6 & 229 & 3 \\
$\mathrm{Sa}$ & 53 & 34 & 12 & 2 & 101 & 0 \\
$\mathrm{KI}$ & 52 & 29 & 3 & 1 & 85 & 1 \\
Oa & 87 & 56 & 14 & 5 & 162 & 1 \\
$\mathrm{~Tb}$ & 110 & 57 & 15 & 6 & 188 & 0 \\
$\mathrm{Sb}$ & 104 & 52 & 13 & 6 & 175 & 1 \\
$\mathrm{~Kb}$ & 90 & 57 & 15 & 5 & 167 & 1 \\
Om & 50 & 27 & 5 & 2 & 84 & 0 \\
Ok & 89 & 32 & 14 & 4 & 139 & 1 \\
Oba & 73 & 54 & 13 & 4 & 144 & 1 \\
Obb & 70 & 33 & 13 & 3 & 119 & 0 \\
Ks & 93 & 63 & 16 & 4 & 176 & 1 \\
Lkoc & 84 & 56 & 16 & 4 & 160 & 1 \\
Lkor & 54 & 28 & 10 & 3 & 95 & 0 \\
Le & 65 & 49 & 12 & 2 & 128 & 6 \\
Li & 70 & 52 & 11 & 2 & 135 & 2 \\
\hline
\end{tabular}

left, hindering verification. Records of $C$. pectinicornis from Åland Islands are rather old (latest record from 1945, all specimens in MZH).

Tipula (Yamatotipula) fendleri Mannheims, 1963

Ks: Kuusamo, Oulanka, Ampumavaara, 20.V.-26.VI.2001, K. Kuusela et al. leg., 4 exx.; Ks: Kuusamo, Oulanka, Ampumavaara, 26.VI.19.VII.2001, K. Kuusela et al. leg., 1 ô.; Li: Inari, Sarmitunturi, Mustajuurakkojärvi N, 2004, J. Salmela leg., 4 exx.; Li: Inari, Sarmitunturi, Kivijoki, 2004, J. Salmela leg., 1 ふ̋; Li: Inari, Sarmitunturi, Pikku-Pahakuru, 2004, J. Salmela leg., 1 đ̊; Li: Inari, Sarmitunturi, Hukkamorosto N, 2004, J. Salmela leg., 1 ふ̋; Lkoc: Muonio, Mustavaara W, 23.VI.2004, J. Salmela leg., 1 đ;; Lkoc: Kittilä, Tarpomapää, 2009, J. Salmela leg., 1 †; Lkoc: Kittilä, Lomajärvenkuru, 2009, J. Salmela leg. 2 †; Lkoc: Kittilä, Pyhätunturi, 25.VI.2009, J. Salmela leg., 1 ๆ.

Comments: This species was described by Mannheims (1963b) from Finland; the type material was collected from a site lying $60 \mathrm{~km}$ SE from the Lake Kilpisjärvi. The species has been hitherto recorded from northern boreal zone, but not from treeless fell areas. Localities are calcareous and non-calcareous springs and spring-fed headwater streams. Tipula fendleri has not been caught outside Finland, but its occurrence in Sweden and Russia is very likely.

\subsection{Doubtful species}

Tipula (Lunatipula) peliostigma Schummel, 1833

This species has been reported from Finland, but without any detailed information on the locality or deposition of voucher specimen (Mannheims 1965c, p. 204 “Frey leg.".) No specimen that could refer to this record has been found from MZH or Zoologisches Forschungsmuseum Alexander Koenig, Bonn (Germany), which are the most likely museums to hold the specimen in question. Although doubtful, this species is retained in the Finnish list. 


\section{List of Finnish crane flies and the occurrence of species in Finnish biogeographical provinces}

A total of 331 crane fly species are recorded from Finland (Appendix 1). Four families are recognized here, following Starý (1992). There are 192 Limoniidae, 113 Tipulidae, 19 Pediciidae and seven Cylindrotomidae species in the Finnish list. The occurrence of 330 crane fly species in the Finnish biogeographical provinces is presented in Appendix 1. Ten species are recorded from all 21 provinces and 27 species are so far recorded from only a single province. The southernmost provinces are the most species rich: Ta (229 spp.), Ab (226 spp.) and N (203 spp., Table 1). Northernmost provinces have lower species richness (Le 128 spp., Li 134 spp., Table 1). There is thus a correlation of decreasing species richness with increasing latitude; this pattern is likely not an artifact due to difference in sampling effort between southern and northern provinces. Compared to their neighboring provinces, $\mathrm{Ka}$ (95 spp.), Om (84 spp.), Obb (119 spp.) and Lkor (95 spp.) have relatively fewer crane fly species. This lesser species richness is likely the result of poor sampling in these regions. Rather low species richness in $\mathrm{Al}$ (116) and $\mathrm{Kl}(85)$ is partly explained by their smaller areal extent and, in the case of $\mathrm{Al}$, location of this province in the Baltic Sea (consisting of one main island and several smaller islands). Although not examined in any detail in this connection, there are regional differences in the Finnish crane fly fauna. Atypopthalmus inustus, Dicranomyia handlirschi, D. liberta, Erioconopa trivialis, Erioptera pederi, Euphylidorea dispar, Molophilus medius, Nephrotoma crocata and Tipula confusa are southern species, not recorded from the northern boreal ecoregion. Some seemingly southern species, viz. Austrolimnophila unica, Ormosia depilata and Tipula vernalis have disjunct occurrences in the valley of the River Teno, Utsjoki (Li). On the other hand, there are several species that are restricted to the northern boreal ecoregion (e.g. Dicranomyia moniliformis, D. lulensis, D. murina, Limonia maculicosta, Symplecta mabelana, Prionocera recta, Tipula subexcisa and Tipula moesta). Dicranomyia sera and D. esbeni may be confined to coastal regions.
Acknowledgements. I would like to show my sincere thanks to Pekka Vilkamaa (MZH), Päivi Tanner (ZMUO) and Antero Suoranta (FOR) for the loan of material. Esko Hyvärinen (Jyväskylä) provided information on the locality of $P$. nigronotata in Janakkala. Pekka Majuri (Oulu) kindly shared his Finnish records of $A$. vitripennis. Special thanks to my former students Olli Autio (Jyväskylä), Teemu Nieminen (Jyväskylä) and Emmi Lehkonen (Jyväskylä) for their trust and co-operation. English text was greatly improved by Fenja Brodo (Ottawa). Comments by three anonymous referees were constructive. I am also grateful to all those persons that have supplied me with crane fly material during all these years. Fine-tuning of the ms was supported by a grant from the Finnish Cultural Foundation (Suomen kulttuurirahasto).

\section{References}

Alexander, C. P. 1920: The crane-flies of New York. Part II. Biology and phylogeny. - Memoirs, Cornell University Agricultural Experiment Station 38: 6911133.

Alexander, C. P. 1964: New or little-known Tipulidae from eastern Asia (Diptera). LIV. - Philippine Journal of Science 93: 277-324.

Autio, O. 2008: Sääskien runsauden ja lajikoostumuksen vuosien väliset vaihtelut luonnontilaisilla latvapuroilla. - MSc thesis, University of Jyväskylä, Department of Biological and Environmental Sciences. 34 pp. [In Finnish.]

Autio, O. \& Salmela, J. 2010: The semi-aquatic fly fauna (Diptera) of wetlands of the Åland Islands. - Memoranda Societas Pro Fauna Flora Fennica 86: 43-53.

Bergroth, E. E. 1888a: Über einige nordamerikanische Tipuliden. I. - Wiener Entomologische Zeitung 7: 193 201.

Bergroth, E. E. 1888b: Über einige nordamerikanische Tipuliden. II. - Wiener Entomologische Zeitung 7: 239-240.

Bergroth, E. E. 1888c: On some South African Tipulidae. — Entomologisk Tidskrift 9: 127-141.

Bergroth, E. E. 1888d: Österreichische Tipuliden, gesammelt von Professor J.A. Palmen im Jahre 1870. - Verhandlungen der Kaiserlich-Königlichen ZoologischBotanischen Gesellschaft in Wien 38: 645-656.

Blackshaw, R. P. \& Coll, C. 1999: Economically important leatherjackets of grassland and cereals: biology, impact and control. - Integrated Pest Management Review 4: 143-160.

Brander, T. 1964: Vaaksiaisten (Tipulidae, Diptera) esiintymisestä ja keräilystä. — Lounais-Hämeen Luonto 16: 30-31. [In Finnish.]

Brindle, A. 1967: The larvae and pupae of the British Cylindrotominae and Limoniinae. - Transactions of the Society for British Entomology 17: 151-216.

Brodo, F. 1987: A revision of the genus Prionocera (Diptera: Tipulidae). — Evolutionary Monographs 8: 1-93.

Brodo, F. 1994: The subgenus Tipula (Tipula) in Finland and Estonia. - Entomologica Fennica 5: 49-52. 
Chernov, Y. I. \& Lantsov, V. I. 1992: Why do Tipulomorpha (Diptera, Insecta) succeed in the arctic conditions. - Acta Zoologica Cracoviensia 35: 193-197.

Frey, R. 1915: Professori Carl Lundström †. — Luonnon Ystävä 19: 12-15. [In Finnish.]

Frey, R. 1921. Beschreibung einer neuen Pedicia-Art aus dem nordlichen Europa (Diptera, Tipulidae). - Notulae Entomologicae 1: 110-112.

Frey, R. 1932: Bidrag till kännedomen om Finlands harkrankar(Dipt.). - Memoranda Societatis Fauna Flora Fennica 9: 29-31. [In Swedish.]

Frey, R. 1934: Tiedonantoja. — Notulae Entomologicae 14: 120. [In Finnish.]

Frey, R., Storå, R. \& Tiensuu, L. 1941: Enumeratio Insectorum Fenniae, VI. Diptera. - Helsinki. 63 pp.

Geiger, W. 1985: Limoniidae (Diptera), sous-famille Limoniinae de Suisse: synonymies nouvelles. - Mitteilungen der Schweizerischen Entomologischen Gesellschaft 58: 69-76.

Geiger, W. 1986: Bibliographie raisonnee des Limoniidae (Diptera Nematocera) de la zone Palaearctique ouest. (Publications 1900-1982). 1. Sous-famille Limoniinae. - Bulletin Romand d'Entomologie 4: 3-121

Gelhaus, J. K. 2005: Systematics and biogeography of the desert crane fly subgenus Tipula (Eremotipula) Alexander (Diptera: Tipulidae). - Memoirs of the American Entomological Society 46: 1-235.

Hackman, W. 1980: A check list of the Finnish Diptera. I. Nematocera and Brachycera (s.str.). - Notulae Entomologicae 60: 17-48.

Hancock, E. G. 2008: Larval habit preferences in Palaearctic Gnophomyia (Diptera, Limoniidae) with a key to adults. - Sahlbergia 14: 13-16.

Ilmonen, J. \& Salmela, J. 2010: 1. Vesihyönteisten ja semiakvaattisten sääskien yhteisövaihtelu suhteessa lähteikköjen luonnontilaan. — In: Juutinen, R. (ed.), Lähteikköjen ennallistamistarve - hyönteislajiston tarkastelu ja koko hankkeen yhteenveto. Metsähallituksen luonnonsuojelujulkaisuja, Sarja A 193: 11-24. [In Finnish.]

Itämies, J. \& Lindgren, E. 1985: The ecology of Chionea species (Diptera, Tipulidae). — Notulae Entomologicae 65: 29-31.

de Jong, H., Oosterbroek, P., Gelhaus, J., Reusch, H. \& Young, C. 2008: Global biodiversity of craneflies (Insecta, Diptera: Tipulidea or Tipulidae sensu lato) in freshwater. - Hydrobiologia 595: 457-467.

Julin, J. 1791-92: Bref til Herr Intendenten Fischerström, om de uti Österbotten, särdeles omkring Uleåborg samlade Naturalier. - Ny Journal för Hushållningen 14:266-293, 15:3-34, 55-73, 105-137. [Insecta 105131] [In Swedish.]

Krogerus, R. 1936: Föreningsmeddelanden. - Tietoja yhdistyksistä. — Notulae Entomologicae 16: 89. [In Swedish and Finnish.]

Krogerus, R. 1937: Zwei neue Diptera Polyneura aus Finnland. - Notulae Entomologicae 17: 57-59.

Krogerus, R. 1960: Ökologische Studien über nordische Mooratrhopoden. Artenbestand, ökologische Fakto- ren, Korrelation der Arten. - Commentationes Biologicae 21: 1-238.

Lackschewitz, P. 1924: Beiträg zur Kenntnis der Tipuliden Finlands (Tipula lateralis Mg. sens. lat.). — Notulae Entomologicae 4: 84-87.

Lackschewitz, P. 1928: Die palaearktischen Limnobiinen (Diptera) des Wiener Naturhistorischen Museums. Annalen des Naturhistorischen Museums Wien 42: 195-244.

Lackschewitz, P. 1932: Tipuliden-Studien, 1 (Dipt., Nematoc. polyn.). — Konowia 11: 74-86.

Lackschewitz, P. 1936: Das Genus Tipula (Diptera Nematocera) in der Arktis und dem borealen Waldgebiet Eurasiens. - Travaux de l'Institut Zoologique de l'Academie des Sciences de l'USSR 4: 245-312.

Lahti, T., Kurtto, A. \& Väisänen, R. A. 1988: Floristic composition and regional species richness of vascular plants in Finland. - Annales Botanici Fennici 25: 281-291.

Lehkonen, E. 2008: Suojavyöhykkeen leveyden ja poimintahakkuiden vaikutukset metsälain määrittelemien purojen sammal- ja sääskilajiston monimuotoisuuden turvaamiskykyyn. - MSc thesis, University of Jyväskylä, Department of Biological and Environmental Sciences. 60 pp. [In Finnish.]

Lindberg, H. 1927-1928: Sketch in commemoration of Ernst Evald Bergroth. - Memoranda Societatis Fauna Flora Fennica 4: 291-317.

Lundström, C. 1907a: Beiträge zur Kenntnis der Dipteren Finnlands, 2. Tipulidae (Tipulidae Longipalpi Ost.Sack.). - Acta Societatis pro Fauna et Flora Fennica 29: 1-27.

Lundström, C. 1907b: Beiträge zur Kenntnis der Dipteren Finnlands, 3. Cylindrotomidae und Limnobiidae. Acta Societatis pro Fauna et Flora Fennica 29: 1-31.

Lundström, C. 1912: Beiträge zur Kenntnis der Dipteren Finnlands, 8, suppl. 2, Mycetophilidae, Tipulidae, Cylindrotomidae und Limnobiidae. - Acta Societatis pro Fauna et Flora Fennica 36: 1-70.

Lundström, C. \& Frey, R. 1916: Beiträge zur Kenntnis der Dipteren Finnlands. 10. Suppl. 4. Bibionidae, Chironomidae, Tipulidae. - Acta Societatis pro Fauna et Flora Fennica 44: 1-26.

MacLean, S. F. 1973: Life cycle and growth energetics of the Arctic crane-fly Pedicia hannai antennata. - Oikos 24: 434-443

Mannheims, B. 1954: Die Tipuliden Ostfennoskandiens (Dipt.). - Notulae Entomologicae 34: 29-50.

Mannheims, B. 1963a: Zwei für Fennoskandien neue Tipula-Arten (Dipt., Tipulinae). — Notulae Entomologicae 43: 37-41.

Mannheims, B. 1963b: Eine Tipula der ostasiatischen "semipterna"-Gruppe in Finnland (Dipt., Tipulidae). Notulae Entomologicae 43: 69-74.

Mannheims, B. 1964a: Tipuliden und Limoniiden aus Südwest-Häme (Finnland). — Lounais-Hämeen Luonto 15: 20-22.

Mannheims, B. 1964b. Die Tipuliden der Sammlung Meigen. - Bonner Zoologische Beitrage 15: 103-108. 
Mannheims, B. 1965a: Enumeratio Tipulidarum Fenniae. — Lounais-Hämeen Luonto 20: 1-3.

Mannheims, B. 1965b: Sechzehn für Finnland neue Limoniiden mit Liste der Tipulidae, Limoniidae, Cylindrotomidae, Liriopeidae, Trichoceridae und Phryneidae (Diptera, Nematocera) Südwest-Hämes. — LounaisHämeen Luonto 20: 4-9.

Mannheims, B. 1965c: 15. Tipulidae. — In: Lindner, E. (ed.), Die Fliegen der palaearktischen Region, 3(5)1, Lief. 256: 177-212.

Mannheims, B. 1967a: Liste der Tipuliden Ostfennoskandiens. - Notulae Entomologicae 47: 77-80.

Mannheims, B. 1967b: Tipula (Vestiplex) bo sp.n. und andere Tipuliden aus Fennoskandien (Diptera). - Notulae Entomologicae 47: 147-156.

Mendl, H. 1971: A new Limonia from Swedish Lapland (Dipt. Tipulidae). - Entomologica Scandinavica 2: 267-268

Mend1, H., Müller, K. \& Viramo, J. 1977: Vorkommen und Verbreitung von Chionea araneoides Dalm., C. crassipes Boh. und C. lutescens Lundstr. (Diptera, Tipulidae) in Nordeuropa. - Notulae Entomologicae 57: 85-90.

Nielsen, P. 1929: Contributions to the knowledge of the Palaearctic Tipulidae. — Notulae Entomologicae 9: 4850.

Nieminen, T. 2008: Merenrantaniittyjen ja -metsien semiakvaattiset sääsket (Diptera, Nematocera) Perämerellä Hailuodossa ja Oulunsalossa. — MSc thesis, University of Jyväskylä, Department of Biological and Environmental Sciences. 41 pp. [In Finnish.]

Oosterbroek, P. 1978: The western palaearctic species of Nephrotoma Meigen, 1803 (Diptera, Tipulidae), part 1. - Beaufortia 27: 1-137.

Oosterbroek, P. 2009: New replacement names in craneflies (Diptera: Limoniidae, Tipulidae). — Zoosymposia 3: $173-177$

Oosterbroek, P. 2011: Catalogue of the Craneflies of the World (Diptera, Tipuloidea: Pediciidae, Limoniidae, Cylindrotomidae, Tipulidae) - [www document]. URL http://ip30.eti.uva.nl/ccw/index.php (Site visited on 16 May, 2011).

Oosterbroek, P. \& Theowald, B. 1992: Family Tipulidae. — In: Soós, Á., Papp, L. \& Oosterbroek, P. (eds.), Catalogue of Palaearctic Diptera 1: 56-178. Hungarian Natural History Museum, Budapest. 463 pp.

Oosterbroek, P., Bygebjerg, R. \& Munk, T. 2006: The west palaearctic species of Ctenophorinae (Diptera: Tipulidae); key, distribution and references. - Entomologische Berichten, Amsterdam 66: 138-149.

Oosterbroek, P. \& Reusch, H. 2008: Review of the European species of the genus Chionea (Dalman, 1816) (Diptera, Limoniidae). - Braunschweiger Naturkundliche Schriften 8: 173-220.

Penttinen, J., Ilmonen, J., Jakovlev, J., Salmela, J., Kuusela, K. \& Paasivirta, L. 2010: Sääsket - Thread-horned flies, Diptera: Nematocera. — In: Rassi, P., Hyvärinen, E., Juslén, A. \& Mannerkoski, I. (eds.), Suomen lajien uhanalaisuus - Punainen kirja 2010. The 2010 Red List of Finnish Species: 477-489. Ympäristömi- nisteriö \& Suomen ympäristökeskus, Helsinki. 683 pp. [In Finnish.]

Petersen, M. J., Bertone, M. A., Wiegmann, B. M. \& Courtney, G. W. 2010: Phylogenetic synthesis of morphological and molecular data reveals new insights into the higher-level classification of Tipuloidea (Diptera). - Systematic Entomology 35: 526545.

Peus, F. 1952. 17. Cylindrotomidae. - In: Lindner, E. (ed.), Die Fliegen der palaearktischen Region, 3(5) 3 , Lief. 169: 1-80.

Polevoi, A. 2001: 4. The study of forest Diptera fauna in Koitajoki area. — In: Hokkanen, T. J. (ed.), Diversity studies in Koitajoki area (North Karelian Biosphere Reserve, Ilomantsi, Finland): 72-85. Metsähallituksen luonnonsuojelujulkaisuja Sarja A, 131. 217 pp.

Rautio, O. 1985: Suomelle uusia lajeja yläheimosta Tipuloidea. - Notulae Entomologicae 65: 166.

Rautio, O. 1986: Suomelle uusi vaaksiainen (Tipulidae). - Notulae Entomologicae 66: 189-190.

Rautio, O. 1987: Suomelle uusi vaaksiainen (Tipulidae). — Notulae Entomologicae 67: 216.

Reusch, H. \& Oosterbroek, P. 1997: Diptera Limoniidae and Pediciidae, Short-palped Crane Flies. — In: Nilsson, A. N. (ed.), Aquatic Insects of Noth Europe - A Taxonomic Handbook: 105-132. Vol. 2.

Salmela, J. 2001: Adult craneflies (Diptera, Nematocera) around springs in southern Finland. - Entomologica Fennica 12: 139-152.

Salmela, J. 2004: Semiaquatic flies (Diptera, Nematocera) of three mires in southern boreal zone, Finland. - Memoranda Societas Pro Fauna Flora Fennica 80: 1-10.

Salmela, J. 2005: Lapin kolmion lähteiden sääskien ja sammalten monimuotoisuus ja yhteisörakenne. MSc thesis, University of Jyväskylä, Department of Biological and Environmental Sciences. 64 pp. [In Finnish.]

Salmela, J. 2006: Suomen vaaksiaiset, kummitussääsket, perhossääsket, sinkilähyttyset ja norosääsket (Diptera, Nematocera) - ekologia, levinneisyys ja uhanalaisuus. Alustava raportti. (Ecology, distribution and redlist status of craneflies, phantom midges, mothflies, meniscus midges and trickle midges in Finland (Diptera, Nematocera). Preliminary report). - Privately published. 75 pp. [In Finnish.]

Salmela, J. 2008: Semiaquatic fly (Diptera, Nematocera) fauna of fens, springs, headwater streams and alpine wetlands in the northern boreal ecoregion, Finland. w-album 6: 3-63.

Salmela, J. 2009: The subgenus Tipula (Pterelachisus) in Finland (Diptera, Tipulidae) - species and biogeographic analysis. - Zoosymposia 3: 255-271.

Salmela, J. 2010: Cranefly (Diptera: Tipuloidea \& Ptychopteridae) fauna of Limhamn limestone quarry (Sweden, Malmö) - diversity and faunistics viewed from a NW European perspective. - Norwegian Journal of Entomology 57: 123-135.

Salmela, J. 2011: The semiaquatic fly (Diptera, Nematocera) assemblages of three wetland habitats and concordance with plant species composition, a case study 
from subalpine Fennoscandia. - Journal of Insect Science 11: 1-28.

Salmela, J. 2012: Revision of Tipula (Yamatotipula) stackelbergi Alexander (Diptera, Tipulidae), and a short discussion on subspecies among crane flies. - ZooKeys 162: 43-58.

Salmela, J. \& Ilmonen, J. 2005: Cranefly fauna of a boreal mire system in relation to mire trophic status (Diptera: Tipuloidea): implications for conservation and bioassesment. — Journal of Insect Conservation 9: 85-94.

Salmela, J. \& Autio, O. 2007: Semiaquatic flies of Kivineva mire, Middle boreal Finland, and redescription of Cylindrotoma borealis Peus, 1952 stat. n. (Diptera, Nematocera). - International Journal of Dipterological Research 18: 47-55.

Salmela, J., Autio, O. \& Ilmonen, J. 2007: A survey on the nematoceran (Diptera) communities of southern Finnish wetlands. - Memoranda Societas Pro Fauna Flora Fennica 83: 33-47.

Salmela, J. \& Starý, J. 2008: Description of Metalimnobia (Metalimnobia) charlesi sp. n. from Europe (Diptera, Limoniidae). - Entomologica Fennica 19: 268-272.

Salmela, J. \& Autio, O. 2009: Tipula moesta Riedel and related species in Finland (Diptera, Tipulidae). — Entomologica Fennica 20: 49-55.

Sandström, J. 2008: Ctenophora nigriceps, gulfläckig vedharkrank — [www document]. URL http://snotra.artdata.slu.se/artfakta/SpeciesInformationDocument/ Ctenophora_Nigriceps_102024.pdf. (Site visited on 27 April, 2011).

Savchenko, E. N., Oosterbroek, P. \& Starý, J. 1992: Family Limoniidae. - In: Soós, Á., Papp, L. \& Oosterbroek, P. (eds.), Catalogue of the Palaearctic Diptera 1: 183374. Hungarian Natural History Museum, Budapest. $463 \mathrm{pp}$.

Savolainen, E. \& Syrjämäki, J. 1971: Swarming and mating of Erioptera gemina Tjeder (Dipt., Limoniidae). - Annales Entomologi Fennici 37: 79-85.

Silfverberg, H. 1986: Additions to the Finnish insect fauna during the years 1981-1985. — Notulae Entomologicae 66: 131-152.

Silfverberg, H. 1996: Changes 1991-1995 in the list of Finnish insects. - Entomologica Fennica 7: 39-49.

Siitonen, O. 1984: Tipuloidea (Diptera) of Inari Lapland. - Kevo Notes 7: 67-69.

Starý, J. 1992: Phylogeny and classification of Tipulomorpha, with special emphasis on the family Limoniidae. - Acta Zoologica Cracoviensia 35: 11-36.

Starý, J. 2004: Revision of European species of the genus Rhabdomastix (Diptera: Limoniidae). Part 2: Subgenus Rhabdomastix s.str. - European Journal of Entomology 101: 657-687.

Starý, J. 2007: Nomenclatural changes in West Palaearctic
Limoniidae and Pediciidae (Diptera), II. - Casopis Slezskeho Musea v Opava (A) 56: 23-36.

Starý, J. 2008: Three new European species of the genus Scleroprocta Edwards, 1938 (Diptera, Limoniidae). - Biologia, Bratislava 63: 120-126.

Starý, J. 2009: New records of Limoniidae, Pediciidae and Tipulidae (Diptera) from the Czech Republic and Slovakia. - Folia Faunistica Slovaca 14: 95-97.

Starý, J. \& Salmela, J. 2004: Redescription and biology of Limonia badia (Walker) (Diptera, Limoniidae). Entomologica Fennica 15: 41-47.

Starý, J. \& Brodo, F. 2009: Arctic species of the subgenus Symplecta sensu stricto (Diptera: Limoniidae). - Canadian Entomologist 141: 1-30.

Starý, J. \& Reusch, H. 2009: European species of the subgenus Brachylimnophila (Diptera: Limoniidae). Entomologica Fennica 19: 207-217.

Tahvonen, E. 1932: Berichte über die Chionea-Arten in Finnland. - Notulae Entomologicae 12: 40-46.

Theowald, B. 1982: 21. Craneflies (Dipt.: Tipulidae) in coastal areas of the Gulf of Bothnia. - In: Müller, K. (ed.), Coastal Research in the Gulf of Bothnia: 263268. Dr W. Junk Publishers, The Hague.

Tjeder, B. 1958: A synopsis of the Swedish Tipulidae, 1. Subfam. Limoniinae: tribe Limoniini. - Opuscula Entomologica 23: 133-169.

Tjeder, B. 1963: Notes on Cheilotrichia areolata (Lundstr.) (Diptera, Limoniidae). — Notulae Entomologicae 43: 133-136.

Tjeder, B. 1965: Notes on Ormosia brevinervis (Lundstr.) (Diptera, Tipulidae). - Notulae Entomologicae 45: 149-153.

Tjeder, B. 1969: Limnophila prolixicornis Bergroth in Lundstrom, 1907, and L. umbrarum Krogerus, 1957. Notes and lectotype designations (Diptera, Tipulidae). — Notulae Entomologicae 49: 254-256.

Tjeder, B. 1973: A new species of Erioptera from Sweden (Dipt. Tipulidae). - Entomologica Scandinavica 4: 111-114.

Viramo, J. 1992: Koillismaan (Ks) vaaksiaisista (Diptera, Tipulidae). - Oulanka Reports 10: 33-40. [In Finnish.]

Väisänen, R., Heliövaara, K. \& Immonen, A. 1992: Biogeography of Northern European insects: province records in multivariate analysis (Saltatoria; Lepidoptera: Sesiidae; Coleoptera: Buprestidae, Cerambycidae). Annales Zoologi Fennici 28: 57-81.

Young, C. W. \& Gelhaus, J. K. 2000: Crane Flies of Pennsylvania: Preliminary checklist and database development with emphasis on aquatic species. - Report submitted to Pennsylvania Wild Resource Conservation Fund: i-ii, 1-256. 
Appendix 1. List of Finnish crane flies (Diptera: Limoniidae, Tipulidae, Pediciidae, Cylindrotomidae) and occurrence of species in national biogeographical provinces (Fig. 2). Tipula (Lunatipula) peliostigma Schummel, 1833, a doubtful Finnish species, is omitted from the list since there are no available records of its presence in the provinces. Species are arranged in alphabetical order within families.

Species

\section{Limoniidae}

Achyrolimonia decemmaculata (Loew, 1873)

Adelphomyia punctum (Meigen, 1818)

Antocha vitripennis (Meigen, 1830)

Arctoconopa forcipata (Lundström, 1915)

A. obscuripes (Zetterstedt, 1851)

A. zonata (Zetterstedt, 1851)

Atypophthalmus inustus (Meigen, 1818)

Austrolimnophila (Archilimnophila) harperi

(Alexander, 1926)

A. unica (Osten Sacken, 1869)

Cheilotrichia (Cheilotrichia) imbuta (Meigen, 1818)

C. (Empeda) areolata (Lundström, 1912)

C. (Empeda) cinerascens (Meigen, 1804)

C. (Empeda) neglecta (Lackschewitz, 1927)

Chionea (Chionea) araneoides Dalman, 1816

C.(C.) crassipes Boheman, 1846

C. (Sphaeconophilus) lutescens Lundström, 1907

Crypteria limnophiloides Bergroth, 1913

Dicranomyia (D.) aperta Wahlgren, 1904

D. (D.) autumnalis (Staeger, 1840)

D. (D.) consimilis (Zetterstedt, 1838)

D. (D.) didyma (Meigen, 1804)

D. (D.) distendens Lundström, 1912

D. (D.) frontalis (Staeger, 1840)

D. (D.) halterata Osten Sacken, 1869

D. (D.) handlirschi Lackschewitz, 1928

D. (D.) hyalinata (Zetterstedt, 1851)

D. (D.) longipennis (Schummel, 1829)

D. (D.) mitis (Meigen, 1830)

D. (D.) modesta (Meigen, 1818)

D. (D.) moniliformis Doane, 1900

D. (D.) omissinervis de Meijere, 1918

D. (D.) patens Lundström, 1907

D. (D.) radegasti Starý, 1993

D. (D.) sera (Walker, 1848)

D. (D.) terraenovae Alexander, 1920

D. (D.) ventralis (Schummel, 1829)

D. (D.) zernyi Lackschewitz, 1928

D. (Glochina) liberta Osten Sacken, 1860

D. (Glochina) tristis (Schummel, 1829)

D. (Idiopyga) danica Kuntze, 1919

D. (Idiopyga) halterella Edwards, 1921

D. (Idiopyga) intricata Alexander, 1927

D. (Idiopyga) Iulensis (Tjeder, 1969)

D. (Idiopyga) magnicauda Lundström, 1912

D. (Idiopyga) esbeni (Nielsen, 1940)

D. (Idiopyga) murina (Zetterstedt, 1851)

D. (Idiopyga) ponojensis Lundström, 1912

\section{Province}

$\mathrm{Ab}, \mathrm{N}, \mathrm{Ka}, \mathrm{Ta}, \mathrm{Tb}, \mathrm{Sb}, \mathrm{Kb}, \mathrm{Ok}$

$\mathrm{Ta}, \mathrm{Sa}, \mathrm{Obb}$

$\mathrm{Sa}, \mathrm{Ok}, \mathrm{Obb}, \mathrm{Li}$

Le

Le

$\mathrm{Ab}, \mathrm{Ta}, \mathrm{KI}, \mathrm{Oa}, \mathrm{Ok}, \mathrm{Oba}, \mathrm{Obb}, \mathrm{Ks}$, Lkor, Le

$\mathrm{Al}, \mathrm{Ab}, \mathrm{N}, \mathrm{Ta}, \mathrm{KI}, \mathrm{Oa}, \mathrm{Tb}$

Oba, Ks, Lkoc, Le, Li

$\mathrm{Ab}, \mathrm{N}, \mathrm{Ka}, \mathrm{St}, \mathrm{Ta}, \mathrm{Sa}, \mathrm{Kl}, \mathrm{Oa}, \mathrm{Tb}, \mathrm{Sb}, \mathrm{Kb}, \mathrm{Ok}$, Li

$\mathrm{Al}, \mathrm{Ab}, \mathrm{N}, \mathrm{Ta}, \mathrm{Kl}, \mathrm{Oa}, \mathrm{Tb}, \mathrm{Sb}, \mathrm{Ok}$

Oa, Om, Oba, Obb, Ks, Lkoc, Le, Li

$\mathrm{Al}, \mathrm{Ab}, \mathrm{N}, \mathrm{Ka}, \mathrm{St}, \mathrm{Ta}, \mathrm{Sa}, \mathrm{Kl}, \mathrm{Oa}, \mathrm{Tb}, \mathrm{Sb}, \mathrm{Kb}, \mathrm{Om}, \mathrm{Ok}$,

Oba, Ks

$\mathrm{Ab}, \mathrm{N}, \mathrm{Ka}, \mathrm{St}, \mathrm{Ta}, \mathrm{Oa}, \mathrm{Tb}, \mathrm{Sb}, \mathrm{Ok}$, Oba

$\mathrm{Ab}, \mathrm{N}, \mathrm{Tb}, \mathrm{Ok}, \mathrm{Oba}, \mathrm{Ks}$

Oba, Lkoc, Lkor

$\mathrm{Ab}, \mathrm{N}, \mathrm{Ta}, \mathrm{Ok}, \mathrm{Oba}, \mathrm{Ks}$

$\mathrm{Al}, \mathrm{Ab}, \mathrm{St}, \mathrm{Ta}, \mathrm{Oa}, \mathrm{Tb}, \mathrm{Sb}, \mathrm{Kb}, \mathrm{Ok}, \mathrm{Oba}, \mathrm{Ks}$

$\mathrm{Tb}, \mathrm{Sb}, \mathrm{Ok}, \mathrm{Obb}, \mathrm{Ks}$, Lkoc

$\mathrm{Al}, \mathrm{Ab}, \mathrm{N}, \mathrm{St}, \mathrm{Ta}, \mathrm{Oa}, \mathrm{Tb}, \mathrm{Sb}, \mathrm{Kb}, \mathrm{Ks}$, Lkoc, Lkor, Li

$\mathrm{Ab}, \mathrm{Ka}, \mathrm{Ta}, \mathrm{Oa}, \mathrm{Tb}, \mathrm{Sb}, \mathrm{Kb}, \mathrm{Ok}, \mathrm{Obb}, \mathrm{Ks}$

$\mathrm{Ab}, \mathrm{Ka}, \mathrm{St}, \mathrm{Ta}, \mathrm{Kl}, \mathrm{Oa}, \mathrm{Tb}, \mathrm{Om}$, Lkoc, Le, Li

$\mathrm{Ab}, \mathrm{N}, \mathrm{St}, \mathrm{Ta}, \mathrm{Sa}, \mathrm{Kl}, \mathrm{Oa}, \mathrm{Tb}, \mathrm{Sb}, \mathrm{Kb}, \mathrm{Om}, \mathrm{Ok}, \mathrm{Oba}, \mathrm{Obb}$,

Ks, Lkoc, Lkor, Le, Li

$\mathrm{Al}, \mathrm{Ab}, \mathrm{N}, \mathrm{Ka}, \mathrm{St}, \mathrm{Ta}, \mathrm{KI}, \mathrm{Oa}, \mathrm{Tb}, \mathrm{Sb}, \mathrm{Kb}, \mathrm{Om}$, Oba, Obb,

Ks, Lkoc, Li

$\mathrm{Ab}, \mathrm{Ta}, \mathrm{Oa}, \mathrm{Tb}, \mathrm{Sb}, \mathrm{Obb}, \mathrm{Lkoc}, \mathrm{Le}, \mathrm{Li}$

$\mathrm{N}, \mathrm{Ta}, \mathrm{Oa}, \mathrm{Sb}$

Ab, Ta, Oa, Tb, Om, Oba, Obb, Ks, Lkoc, Le, Li

$\mathrm{Obb}, \mathrm{Ks}$, Lkoc

$\mathrm{Al}, \mathrm{Ab}, \mathrm{St}, \mathrm{Ta}, \mathrm{Sa}, \mathrm{Kl}, \mathrm{Tb}, \mathrm{Sb}, \mathrm{Kb}$, Oba, Ks, Le, Li

$\mathrm{Al}, \mathrm{Ab}, \mathrm{N}, \mathrm{Ka}$, St, Ta, Sa, KI, Oa, Tb, Sb, Kb, Om, Ok,

Oba, Obb, Ks, Lkoc, Lkor, Le, Li

Lkoc, Le

Obb, Ks, Lkoc

$\mathrm{Ab}, \mathrm{N}, \mathrm{St}, \mathrm{Ta}, \mathrm{KI}, \mathrm{Oa}, \mathrm{Tb}, \mathrm{Sb}, \mathrm{Obb}, \mathrm{Ks}$, Lkoc, Le, Li $\mathrm{N}$

$\mathrm{Al}, \mathrm{Ab}, \mathrm{N}, \mathrm{Oba}$

$\mathrm{Al}, \mathrm{Ab}, \mathrm{N}, \mathrm{St}, \mathrm{Ta}, \mathrm{Sa}, \mathrm{Tb}, \mathrm{Sb}, \mathrm{Kb}, \mathrm{Ok}, \mathrm{Oba}, \mathrm{Obb}, \mathrm{Ks}$, Lkoc, Lkor, Le, Li

$\mathrm{Al}, \mathrm{Ab}, \mathrm{N}, \mathrm{Ta}, \mathrm{Tb}, \mathrm{Sb}, \mathrm{Kb}$, Lkoc, Lkor, Le, Li

$\mathrm{Tb}, \mathrm{Sb}, \mathrm{Kb}, \mathrm{Ok}$

$\mathrm{N}, \mathrm{Ta}, \mathrm{Tb}, \mathrm{Ok}$

$\mathrm{Ab}, \mathrm{N}, \mathrm{Ta}, \mathrm{Tb}, \mathrm{Sb}, \mathrm{Ks}$

$\mathrm{Al}, \mathrm{Ab}, \mathrm{Sa}$

$\mathrm{Ab}, \mathrm{N}, \mathrm{St}, \mathrm{Ta}$

Oba, Lkoc, Lkor, Le

Ks, Lkor, Le

$\mathrm{Al}, \mathrm{Ab}, \mathrm{N}, \mathrm{Ta}, \mathrm{Kl}, \mathrm{Oa}, \mathrm{Tb}, \mathrm{Om}$, Ks, Lkoc, Lkor

Oba

Ks, Lkor, Li

Tb, Ok, Oba, Obb, Ks, Lkoc, Lkor, Le, Li 
D. (Idiopyga) stigmatica (Meigen, 1830)

D. (Melanolimonia) caledonica Edwards, 1926

D. (Melanolimonia) morio (Fabricius, 1787)

D. (Melanolimonia) occidua Edwards, 1926

D. (Melanolimonia) rufiventris (Strobl, 1900)

D. (Melanolimonia) stylifera Lackschewitz, 1928

D. (Numantia) fusca (Meigen, 1804)

Dicranophragma (Brachylimnophila) separatum (Walker, 1848)

Dicranoptycha cinerascens (Meigen, 1818)

D. fuscescens (Schummel, 1829)

Discobola annulata (Linnaeus, 1758)

D. caesarea (Osten Sacken, 1854)

Elephantomyia (E.) edwardsi Lackschewitz, 1932 E. krivosheinae Savchenko, 1976

Eloeophila maculata (Meigen, 1804)

E. submarmorata (Verrall, 1887)

E. trimaculata (Zetterstedt, 1838)

E. verralli (Bergroth, 1912)

Epiphragma (E.) ocellare (Linnaeus, 1760)

Erioconopa diuturna (Walker, 1848)

E. trivialis (Meigen, 1818)

Erioptera (E.) beckeri Kuntze, 1914

E. (E.) divisa (Walker, 1848)

E. (E.) flavata (Westhoff, 1882)

E. (E.) griseipennis Meigen, 1838

E. (E.) lutea Meigen, 1804

E. (E.) nielseni de Meijere, 1921

E. (E.) pederi Tjeder, 1969

E. (E.) sordida Zetterstedt, 1838

E. (E.) squalida Loew, 1871

E. (E.) tordi Tjeder, 1973

Euphylidorea dispar (Meigen, 1818)

E. meigenii (Verrall, 1886)

E. phaeostigma (Schummel, 1829)

Eutonia barbipes (Meigen, 1804)

Gnophomyia acheron Alexander, 1950

G. lugubris (Zetterstedt, 1838)

G. viridipennis (Gimmerthal, 1847)

Gonempeda flava (Schummel, 1829)

Gonomyia (G.) abscondita Lackschewitz, 1935

G. (G.) bifida Tonnoir, 1920

G. (G.) dentata de Meijere, 1920

G. (G.) simplex Tonnoir, 1920

G. (G.) stackelbergi Lackschewitz, 1935

G. (G.) tenella (Meigen, 1818)

G. (Teuchogonomyia) edwardsi Lackschewitz, 1925

Helius $(H$.$) flavus (Walker, 1856)$

$H$. $(H$.$) longirostris (Meigen, 1818)$

H. (H.) pallirostris Edwards, 1921
Al, Ab, N, St, Ta, Oa, Tb, Sb, Kb, Obb, Ks, Lkoc, Lkor, Le, $\mathrm{Li}$

Lkoc, Le, Li

Al, Ab, N, Ka, St, Ta, Oa, Tb, Sb, Om, Oba, Obb, ks, Lkoc, Le

$\mathrm{Kb}, \mathrm{Ok}, \mathrm{Oba}, \mathrm{Obb}, \mathrm{Ks}$

$\mathrm{Ab}, \mathrm{St}, \mathrm{Ta}, \mathrm{Tb}, \mathrm{Sb}, \mathrm{Kb}, \mathrm{Om}, \mathrm{Ok}, \mathrm{Oba}, \mathrm{Obb}, \mathrm{ks}$, Lkoc, Lkor, Le, Li

Ks, Le, Li

$\mathrm{Ab}, \mathrm{N}, \mathrm{St}$, ta, Tb, Sb, Kb, Ok

$\mathrm{Al}, \mathrm{Ab}, \mathrm{N}, \mathrm{Ka}, \mathrm{St}, \mathrm{Ta}, \mathrm{Sa}, \mathrm{KI}, \mathrm{Oa}, \mathrm{Tb}, \mathrm{Sb}, \mathrm{Kb}, \mathrm{Om}, \mathrm{Ok}$,

Oba, Obb, Ks, Lkoc, Lkor, Le, Li

$\mathrm{Ta}, \mathrm{Sa}$

$\mathrm{Ab}, \mathrm{Ta}$

$\mathrm{Ab}, \mathrm{N}, \mathrm{Ka}, \mathrm{St}, \mathrm{Ta}, \mathrm{Sa}, \mathrm{Oa}, \mathrm{Tb}, \mathrm{Sb}, \mathrm{Kb}, \mathrm{Om}, \mathrm{Ok}, \mathrm{Oba}, \mathrm{Obb}$, Ks, Lkoc

Ab, N, St, Ta, Sa, KI, Oa, Tb, Sb, Kb, Ok, Oba, Obb, Ks, Lkoc

$\mathrm{N}, \mathrm{Ta}$

$\mathrm{Ab}, \mathrm{N}, \mathrm{Ta}, \mathrm{Sa}, \mathrm{Tb}, \mathrm{Sb}, \mathrm{Kb}, \mathrm{Ok}, \mathrm{Obb}, \mathrm{Ks}$, Lkoc

$\mathrm{Ab}, \mathrm{N}, \mathrm{Ka}, \mathrm{St}, \mathrm{Ta}, \mathrm{Sa}, \mathrm{Oa}, \mathrm{Tb}, \mathrm{Sb}, \mathrm{Kb}, \mathrm{Ok}, \mathrm{Oba}, \mathrm{Obb}, \mathrm{Ks}$, Lkoc

$\mathrm{Ab}, \mathrm{N}, \mathrm{Ta}, \mathrm{Oa}$

$\mathrm{Ab}, \mathrm{N}, \mathrm{Ka}, \mathrm{St}$, ta, Sa, KI, Oa, Tb, Sb, Kb, Ok, Oba, Obb, Ks, Lkoc, Lkor, Le, Li

$\mathrm{Ta}$

$\mathrm{Al}, \mathrm{Ab}, \mathrm{N}, \mathrm{Ka}, \mathrm{St}, \mathrm{Ta}, \mathrm{Kl}, \mathrm{Oa}, \mathrm{Tb}, \mathrm{Sb}, \mathrm{Kb}, \mathrm{Ok}$

$\mathrm{Oa}, \mathrm{Tb}, \mathrm{Sb}, \mathrm{Kb}, \mathrm{Ok}, \mathrm{Oba}, \mathrm{Obb}, \mathrm{Ks}$, Lkoc, Lkor, Le, Li

$\mathrm{Al}, \mathrm{Ab}, \mathrm{N}, \mathrm{St}, \mathrm{Ta}, \mathrm{Sa}, \mathrm{Oa}, \mathrm{Tb}, \mathrm{Sb}, \mathrm{Kb}, \mathrm{Oba}, \mathrm{Obb}$

$\mathrm{Al}, \mathrm{Ab}, \mathrm{N}, \mathrm{Ta}, \mathrm{Sa}, \mathrm{Kl}, \mathrm{Oa}, \mathrm{Tb}, \mathrm{Sb}, \mathrm{Kb}, \mathrm{Ok}$, Lkoc, Le, Li

$\mathrm{Ab}, \mathrm{N}, \mathrm{Ka}, \mathrm{Ta}, \mathrm{Oa}, \mathrm{Sb}$

$\mathrm{Al}, \mathrm{Ab}, \mathrm{N}, \mathrm{Ka}, \mathrm{St}, \mathrm{Ta}, \mathrm{Kl}, \mathrm{Oa}, \mathrm{Tb}, \mathrm{Sb}, \mathrm{Kb}, \mathrm{Om}, \mathrm{Ok}, \mathrm{Oba}$, $\mathrm{Obb}, \mathrm{Ks}$, Lkoc, Lkor, Le, Li

$\mathrm{Al}, \mathrm{Ab}$

$\mathrm{Al}, \mathrm{Ab}, \mathrm{N}, \mathrm{Ka}, \mathrm{St}, \mathrm{Ta}, \mathrm{Sa}, \mathrm{KI}, \mathrm{Oa}, \mathrm{Tb}, \mathrm{Sb}, \mathrm{Kb}, \mathrm{Ok}, \mathrm{Oba}$, Obb, Ks, Lkoc, Lkor, Le, Li

$\mathrm{Al}, \mathrm{Ab}, \mathrm{N}, \mathrm{Ta}, \mathrm{Oa}, \mathrm{Tb}, \mathrm{Sb}, \mathrm{Kb}, \mathrm{Ok}, \mathrm{Obb}, \mathrm{Ks}$, Lkoc

$\mathrm{Ab}, \mathrm{N}, \mathrm{Ta}, \mathrm{Sb}$

$\mathrm{Al}, \mathrm{Ab}, \mathrm{N}, \mathrm{Ka}$, St, Ta, KI, Oa, Tb, Sb, Kb, Om, Ok, Oba, Obb, Ks, Lkoc, Lkor, Li

$\mathrm{Ab}, \mathrm{N}, \mathrm{Ta}, \mathrm{Sb}, \mathrm{Oba}$, Lkoc

$\mathrm{Sb}$

$\mathrm{Al}, \mathrm{Ab}, \mathrm{N}, \mathrm{Ta}, \mathrm{KI}$

Al, St, Oa, Tb, Sb, Kb, Ok, Oba, Ks, Lkoc, Lkor, Le, Li $\mathrm{Al}, \mathrm{Ab}, \mathrm{N}, \mathrm{Ka}, \mathrm{St}, \mathrm{Ta}, \mathrm{Sa}, \mathrm{KI}, \mathrm{Oa}, \mathrm{Tb}, \mathrm{Sb}, \mathrm{Kb}, \mathrm{Om}, \mathrm{Ok}$, Oba, Obb, Ks, Lkoc, Lkor, Le, Li

$\mathrm{Ab}, \mathrm{N}, \mathrm{St}, \mathrm{Ta}$

$\mathrm{Sb}, \mathrm{Ok}$

$\mathrm{Ab}, \mathrm{N}, \mathrm{Tb}, \mathrm{Sb}, \mathrm{Ok}$

$\mathrm{Al}, \mathrm{N}, \mathrm{Ta}$

$A b$

$\mathrm{N}, \mathrm{St}, \mathrm{Ta}, \mathrm{Sb}, \mathrm{Kb}$

$\mathrm{Na}, \mathrm{Ta}$

$\mathrm{N}, \mathrm{St}, \mathrm{Oa}, \mathrm{Tb}, \mathrm{Sb}$

$\mathrm{Al}, \mathrm{Ab}, \mathrm{N}, \mathrm{St}, \mathrm{Ta}, \mathrm{Ok}, \mathrm{Obb}$

Ok, Oba, Obb, Lkoc, Lkor, Le, Li

$\mathrm{N}, \mathrm{Ta}$

$\mathrm{Ta}, \mathrm{KI}$

$\mathrm{Al}, \mathrm{Ab}, \mathrm{N}, \mathrm{St}, \mathrm{Ta}, \mathrm{KI}$

$\mathrm{Al}, \mathrm{Ab}, \mathrm{N}, \mathrm{Ka}, \mathrm{St}, \mathrm{Ta}, \mathrm{KI}, \mathrm{Oa}, \mathrm{Tb}, \mathrm{Sb}, \mathrm{Kb}, \mathrm{Om}, \mathrm{Ok}, \mathrm{Oba}$, $\mathrm{Obb}, \mathrm{Ks}$, Lkoc

$A b$ 
Hexatoma $(H$.$) fuscipennis (Curtis, 1836)$

Hoplolabis (Parilisia) areolata (Siebke, 1872)

H. (P.) vicina (Tonnoir, 1920)

Idioptera linnei Oosterbroek, 1992

I. pulchella (Meigen, 1830)

Libnotes (Afrolimonia) ladogensis

(Lackschewitz, 1940)

Limnophila (L.) pictipennis (Meigen, 1818)

L. (L.) schranki Oosterbroek, 1992

Limonia badia (Walker, 1848)

L. flavipes (Fabricius, 1787)

L. macrostigma (Schummel, 1829)

L. maculicosta (Coquillett, 1905)

L. messaurea Mendl, 1971

L. nubeculosa Meigen, 1804

L. phragmitidis (Schrank, 1781)

L. stigma (Meigen, 1818)

L. sylvicola (Schummel, 1829)

L. trivittata (Schummel, 1829)

Lipsothrix ecucullata Edwards, 1938

L. errans (Walker, 1848)

Metalimnobia (M.) bifasciata (Schrank, 1781)

M. (M.) charlesi Salmela \& Starý 2008

M. (M.) quadrimaculata (Linnaeus, 1760)

M. (M.) quadrinotata (Meigen, 1818)

M. (M.) tenua Savchenko, 1976

M. (M.) zetterstedti (Tjeder, 1968)

Molophilus (M.) appendiculatus (Staeger, 1840) M. (M.) ater (Meigen, 1804)

M. (M.) bifidus Goetghebuer, 1920

M. (M.) bihamatus de Meijere, 1918

M. (M.) cinereifrons de Meijere, 1920

M. (M.) corniger de Meijere, 1920

M. (M.) crassipygus de Meijere, 1918

M. (M.) flavus Goetghebuer, 1920

M. (M.) griseus (Meigen, 1804)

M. (M.) medius de Meijere, 1918

M. (M.) obscurus (Meigen, 1818) ${ }^{1}$

M. (M.) occultus de Meijere, 1918

M. (M.) ochraceus (Meigen, 1818)

M. (M.) propinquus (Egger, 1863)

M. (M.) pullus Lackschewitz, 1927

Neolimnomyia (N.) batava (Edwards, 1938)

Neolimnophila carteri (Tonnoir, 1921)

N. placida (Meigen, 1830)

Neolimonia dumetorum (Meigen, 1804)

Orimarga (O.) attenuata (Walker, 1848)
Ok, Oba, Ks, Lkoc, Lkor, Le, Li

$\mathrm{Ab}, \mathrm{N}, \mathrm{Ta}, \mathrm{ks}$

$\mathrm{Ab}, \mathrm{St}, \mathrm{Ta}, \mathrm{Kl}, \mathrm{Oa}, \mathrm{Tb}, \mathrm{Sb}, \mathrm{Om}$, Le

$\mathrm{Ab}, \mathrm{N}, \mathrm{Ta}, \mathrm{Oa}, \mathrm{Tb}, \mathrm{Sb}, \mathrm{Kb}, \mathrm{Om}$, Oba, Obb, Ks, Lkoc, Lkor, Le, Li

$\mathrm{Ab}, \mathrm{N}, \mathrm{Ka}, \mathrm{St}, \mathrm{Ta}, \mathrm{Sa}, \mathrm{Oa}, \mathrm{Tb}, \mathrm{Sb}, \mathrm{Kb}, \mathrm{Om}, \mathrm{Ok}, \mathrm{Oba}, \mathrm{Obb}$, Ks, Lkoc, Lkor, Le, Li

$\mathrm{N}, \mathrm{Ta}, \mathrm{Kb}$

Ta

$\mathrm{Ab}, \mathrm{N}, \mathrm{Ka}, \mathrm{St}, \mathrm{Ta}, \mathrm{KI}, \mathrm{Oa}, \mathrm{Tb}, \mathrm{Sb}, \mathrm{Kb}, \mathrm{Ok}, \mathrm{Oba}, \mathrm{Obb}, \mathrm{Ks}$, Lkoc, Le

$\mathrm{Ta}, \mathrm{Tb}, \mathrm{Sb}, \mathrm{Kb}, \mathrm{Ok}, \mathrm{Obb}$

$\mathrm{Al}, \mathrm{Ab}, \mathrm{N}, \mathrm{St}, \mathrm{Ta}, \mathrm{Sa}, \mathrm{KI}, \mathrm{Oa}, \mathrm{Tb}, \mathrm{Sb}, \mathrm{Kb}, \mathrm{Ok}, \mathrm{Ks}, \mathrm{Li}$

$\mathrm{Al}, \mathrm{Ab}, \mathrm{N}, \mathrm{St}, \mathrm{Ta}, \mathrm{Sa}, \mathrm{KI}, \mathrm{Oa}, \mathrm{Tb}, \mathrm{Sb}, \mathrm{Kb}, \mathrm{Om}, \mathrm{Ok}, \mathrm{Oba}$,

Obb, Ks, Lkoc, Le, Li

$\mathrm{Li}$

Ok

$\mathrm{Al}, \mathrm{Ab}, \mathrm{N}, \mathrm{Ka}, \mathrm{St}, \mathrm{Ta}, \mathrm{Oa}, \mathrm{Sb}$

$\mathrm{Al}, \mathrm{Ab}, \mathrm{N}, \mathrm{Ka}, \mathrm{St}, \mathrm{Ta}, \mathrm{Sa}, \mathrm{Oa}, \mathrm{Tb}, \mathrm{Sb}, \mathrm{Kb}, \mathrm{Om}, \mathrm{Ok}, \mathrm{Ks}$,

Lkoc

$\mathrm{Ab}, \mathrm{Ta}, \mathrm{Le}, \mathrm{Li}$

$\mathrm{Al}, \mathrm{Ab}, \mathrm{N}, \mathrm{St}, \mathrm{Ta}, \mathrm{Oa}, \mathrm{Tb}, \mathrm{Sb}, \mathrm{Kb}, \mathrm{Ok}, \mathrm{Oba}, \mathrm{Obb}, \mathrm{Ks}, \mathrm{Lkoc}$, Lkor, Le, Li

$\mathrm{Al}, \mathrm{Ab}, \mathrm{N}, \mathrm{Ka}, \mathrm{St}, \mathrm{Ta}, \mathrm{Oa}, \mathrm{Tb}, \mathrm{Sb}, \mathrm{Kb}, \mathrm{Om}, \mathrm{Ok}, \mathrm{Oba}, \mathrm{Obb}$,

Ks, Lkoc, Lkor

$\mathrm{Ab}, \mathrm{N}, \mathrm{St}$, ta, Sa, Oa, Tb, Sb, Kb, Ok, Ks $\mathrm{N}$

$\mathrm{Al}, \mathrm{Ab}, \mathrm{N}, \mathrm{Ka}, \mathrm{St}, \mathrm{Ta}, \mathrm{Sa}, \mathrm{Kl}, \mathrm{Oa}, \mathrm{Tb}, \mathrm{Sb}, \mathrm{Kb}, \mathrm{Om}, \mathrm{Ok}$, Oba, Obb, Ks, Lkoc, Lkor, Li

$\mathrm{Ab}, \mathrm{N}, \mathrm{Ta}, \mathrm{Sa}, \mathrm{Tb}, \mathrm{Sb}, \mathrm{Kb}, \mathrm{Ok}, \mathrm{Obb}, \mathrm{Ks}$, Lkoc

$\mathrm{Al}, \mathrm{Ab}, \mathrm{N}, \mathrm{Ka}$, St, Ta, Sa, KI, Oa, Tb, Sb, Kb, Om, Ok, Oba, Obb, Ks, Lkoc, Lkor, Le, Li

$\mathrm{Al}, \mathrm{Ab}, \mathrm{N}, \mathrm{Ka}, \mathrm{St}, \mathrm{Ta}, \mathrm{Sa}, \mathrm{KI}, \mathrm{Oa}, \mathrm{Tb}, \mathrm{Sb}, \mathrm{Kb}, \mathrm{Om}, \mathrm{Ok}$,

Oba, Obb, Ks, Lkoc, Lkor, Le, Li

$\mathrm{Ab}, \mathrm{N}, \mathrm{St}, \mathrm{Ta}, \mathrm{Sa}, \mathrm{KI}, \mathrm{Oa}, \mathrm{Tb}, \mathrm{Sb}, \mathrm{Kb}, \mathrm{Om}, \mathrm{Ok}$, Lkoc

$\mathrm{Al}, \mathrm{Ab}, \mathrm{N}, \mathrm{Ka}, \mathrm{St}, \mathrm{Ta}, \mathrm{Sa}, \mathrm{Kl}, \mathrm{Oa}, \mathrm{Tb}, \mathrm{Sb}, \mathrm{Kb}, \mathrm{Om}, \mathrm{Ok}$,

Oba, Obb, Ks, Lkoc, Lkor, Le, Li

$\mathrm{Al}, \mathrm{Ab}, \mathrm{N}, \mathrm{St}, \mathrm{Ta}, \mathrm{Sa}, \mathrm{KI}, \mathrm{Oa}, \mathrm{Tb}, \mathrm{Sb}, \mathrm{Kb}, \mathrm{Ok}, \mathrm{Ks}$

$\mathrm{Ab}, \mathrm{N}, \mathrm{Ka}, \mathrm{Ta}, \mathrm{Sa}, \mathrm{Kl}, \mathrm{Oa}, \mathrm{Tb}, \mathrm{Sb}, \mathrm{Kb}, \mathrm{Om}, \mathrm{Ok}, \mathrm{Oba}, \mathrm{Obb}$,

Ks, Lkoc, Lkor, Le, Li

$\mathrm{Ab}, \mathrm{St}, \mathrm{Ta}$, Lkoc

$\mathrm{Ab}, \mathrm{N}, \mathrm{Ka}, \mathrm{Ta}, \mathrm{Sa}, \mathrm{KI}, \mathrm{Tb}, \mathrm{Sb}, \mathrm{Om}, \mathrm{Ks}$

$\mathrm{Al}, \mathrm{Ab}, \mathrm{N}, \mathrm{Ta}, \mathrm{Oa}, \mathrm{Tb}, \mathrm{Sb}, \mathrm{Om}$

$\mathrm{Ab}, \mathrm{N}, \mathrm{St}, \mathrm{Ta}, \mathrm{Tb}, \mathrm{Sb}, \mathrm{Kb}$

$\mathrm{Ab}, \mathrm{N}, \mathrm{Ka}, \mathrm{St}, \mathrm{Ta}, \mathrm{Sa}, \mathrm{Oa}, \mathrm{Tb}, \mathrm{Sb}, \mathrm{Kb}, \mathrm{Ok}, \mathrm{Oba}, \mathrm{Obb}, \mathrm{Ks}$, Lkoc, Lkor, Le, Li

$\mathrm{Al}, \mathrm{Ab}, \mathrm{N}, \mathrm{Ka}, \mathrm{St}, \mathrm{Ta}, \mathrm{Sa}, \mathrm{Oa}, \mathrm{Tb}, \mathrm{Sb}, \mathrm{Kb}, \mathrm{Ok}, \mathrm{Oba}, \mathrm{Obb}$, Ks, Lkoc, Lkor, Le, Li

$\mathrm{Al}, \mathrm{Ab}, \mathrm{N}, \mathrm{Ka}, \mathrm{St}, \mathrm{Ta}, \mathrm{KI}, \mathrm{Oa}, \mathrm{Tb}, \mathrm{Kb}, \mathrm{Ks}$

$\mathrm{Ab}, \mathrm{N}, \mathrm{Ka}, \mathrm{Ta}, \mathrm{Sa}, \mathrm{Tb}, \mathrm{Sb}, \mathrm{Ok}$

$\mathrm{N}$

$\mathrm{Ta}$

$\mathrm{Al}, \mathrm{Ab}, \mathrm{N}, \mathrm{Ta}, \mathrm{KI}, \mathrm{Oa}, \mathrm{Tb}, \mathrm{Sb}, \mathrm{Om}, \mathrm{Ok}$

$\mathrm{Ab}, \mathrm{N}, \mathrm{Ka}, \mathrm{St}, \mathrm{Ta}, \mathrm{Kl}, \mathrm{Oa}, \mathrm{Tb}, \mathrm{Sb}, \mathrm{Kb}, \mathrm{Om}, \mathrm{Ks}$, Lkoc, Lkor, Le, Li

$\mathrm{Ab}, \mathrm{N}$

$\mathrm{Ab}, \mathrm{N}, \mathrm{Ta}$

$\mathrm{Ab}, \mathrm{N}, \mathrm{St}, \mathrm{Ta}, \mathrm{Oa}, \mathrm{Tb}, \mathrm{Sb}, \mathrm{Kb}$

$\mathrm{Ab}, \mathrm{Ka}, \mathrm{St}, \mathrm{Ta}, \mathrm{Kl}, \mathrm{Tb}, \mathrm{Kb}$, Oba

$\mathrm{Al}, \mathrm{Ab}, \mathrm{N}, \mathrm{Ka}, \mathrm{St}, \mathrm{Ta}, \mathrm{Sa}, \mathrm{KI}, \mathrm{Tb}, \mathrm{Sb}, \mathrm{Kb}, \mathrm{OK}$

Tb, Ok, Obb, Ks, Lkoc, Lkor, Le, Li 
O. (O.) juvenilis (Zetterstedt, 1851)

Ormosia (Oreophila) sootryeni (Lackschewitz, 1935)

O. (Ormosia) brevinervis (Lundström, 1907)

O. (O.) clavata (Tonnoir, 1920)

O. (O.) depilata Edwards, 1938

O. (O.) fascipennis (Zetterstedt, 1838)

O. (O.) lineata (Meigen, 1804)

O. (O.) loxia Starý, 1983

O. (O.) pseudosimilis (Lundström, 1912)

O. (O.) ruficauda (Zetterstedt, 1838)

O. (O.) staegeriana Alexander, 1953

Paradelphomyia (Oxyrhiza) fuscula (Loew, 1873)

P. (O.) nigrina (Lackschewitz, 1940)

Phylidorea (Macrolabina) nigronotata (Siebke, 1870)

P. (Paraphylidorea) fulvonervosa (Schummel, 1829)

P. (P.) abdominalis (Staeger, 1840)

P. (P.) bicolor (Meigen, 1804)

$P$. (P.) ferruginea (Meigen, 1818)

$P .(P$.$) heterogyna (Bergroth, 1913)$

P. (P.) longicornis (Schummel, 1829)

P. (P.) nervosa (Schummel, 1829)

$P .(P$.$) squalens (Zetterstedt, 1838)$

P. (P.) umbrarum (Krogerus, 1937)

Phyllolabis macroura (Siebke, 1863)

Pilaria decolor (Zetterstedt, 1851)

P. discicollis (Meigen, 1818)

P. meridiana (Staeger, 1840)

P. nigropunctata (Agrell, 1945)

$P$. scutellata (Staeger, 1840)

Pseudolimnophila (P.) lucorum (Meigen, 1818)

Rhabdomastix $(R$.) borealis Alexander, 1924

R. (R.) laeta (Loew, 1873)

$R$. (unplaced) parva (Siebke, 1863)

Rhipidia (R.) maculata Meigen, 1818

Oba, Obb, Ks, Lkoc, Lkor, Le, Li

$R$. (R.) uniseriata Schiner, 1864

Rhypholophus haemorrhoidalis (Zetterstedt, 1838)

$R$. varius (Meigen, 1818)

Scleroprocta pentagonalis (Loew, 1873)

S. sororcula (Zetterstedt, 1851)

Symplecta (Psiloconopa) lindrothi (Tjeder, 1955)

S. $(P$.$) meigeni (Zetterstedt, 1838)$

S. (P.) stictica (Meigen, 1818)

S. (S.) chosenensis (Alexander, 1940)

S. (S.) hybrida (Meigen, 1804)

S. (S.) mabelana (Alexander, 1955)

S. (S.) scotica (Edwards, 1938)
Oba, Lkoc

$\mathrm{Ab}, \mathrm{N}, \mathrm{St}, \mathrm{Oa}, \mathrm{Tb}, \mathrm{Sb}, \mathrm{Kb}, \mathrm{Ks}$

Le

$\mathrm{Ab}, \mathrm{N}, \mathrm{St}, \mathrm{Ta}, \mathrm{Tb}, \mathrm{Kb}$

$\mathrm{Al}, \mathrm{Ab}, \mathrm{N}, \mathrm{Ka}, \mathrm{St}, \mathrm{Ta}, \mathrm{Sa}, \mathrm{Kl}, \mathrm{Oa}, \mathrm{Tb}, \mathrm{Sb}, \mathrm{Kb}, \mathrm{Om}, \mathrm{Ok}$,

Oba, Li

$\mathrm{Ab}, \mathrm{Ks}$, Lkoc, Lkor, Le, Li

$\mathrm{Al}, \mathrm{Ab}, \mathrm{N}, \mathrm{Ka}, \mathrm{St}, \mathrm{Ta}, \mathrm{Sa}, \mathrm{KI}, \mathrm{Oa}, \mathrm{Tb}, \mathrm{Sb}, \mathrm{Kb}, \mathrm{Om}$

$\mathrm{Ab}, \mathrm{N}, \mathrm{St}, \mathrm{Ta}$

$\mathrm{Al}, \mathrm{Ab}, \mathrm{N}, \mathrm{St}, \mathrm{Ta}, \mathrm{Oa}, \mathrm{Tb}, \mathrm{Sb}, \mathrm{Kb}, \mathrm{Om}, \mathrm{Ok}, \mathrm{Oba}, \mathrm{Obb}, \mathrm{Ks}$, Lkoc, Lkor

$\mathrm{Al}, \mathrm{Ab}, \mathrm{N}, \mathrm{Ka}, \mathrm{St}, \mathrm{Ta}, \mathrm{Sa}, \mathrm{Kl}, \mathrm{Oa}, \mathrm{Tb}, \mathrm{Sb}, \mathrm{Kb}, \mathrm{Om}, \mathrm{Ok}$,

Oba, Obb, Ks, Lkoc, Lkor, Le, Li

$\mathrm{Al}, \mathrm{Ab}, \mathrm{N}, \mathrm{St}, \mathrm{Ta}, \mathrm{Sa}, \mathrm{Oa}, \mathrm{Tb}, \mathrm{Sb}, \mathrm{Kb}, \mathrm{Om}, \mathrm{Ok}, \mathrm{Obb}, \mathrm{Ks}$,

Lkoc, Lkor, Le, Li

$\mathrm{Ab}, \mathrm{N}, \mathrm{Ka}, \mathrm{St}, \mathrm{Ta}, \mathrm{Oa}, \mathrm{Tb}, \mathrm{Sb}, \mathrm{Kb}$

$\mathrm{Ta}, \mathrm{Sb}, \mathrm{Lkoc}$

$\mathrm{Ta}, \mathrm{Ks}$

$\mathrm{Al}, \mathrm{Ab}, \mathrm{N}, \mathrm{Ka}, \mathrm{St}, \mathrm{Ta}, \mathrm{Sa}, \mathrm{KI}, \mathrm{Oa}, \mathrm{Tb}, \mathrm{Sb}, \mathrm{Kb}, \mathrm{Om}, \mathrm{Ok}$,

Oba, Obb, Ks, Lkoc, Lkor, Li

$\mathrm{Al}, \mathrm{Ab}, \mathrm{N}, \mathrm{Ka}, \mathrm{Ta}, \mathrm{Oa}, \mathrm{Tb}, \mathrm{Sb}, \mathrm{Kb}, \mathrm{Om}, \mathrm{Ok}, \mathrm{Obb}, \mathrm{Ks}$, Lkoc, Lkor, Le, Li

$\mathrm{Al}, \mathrm{Ab}, \mathrm{N}, \mathrm{Ka}, \mathrm{St}, \mathrm{Ta}, \mathrm{Sa}, \mathrm{KI}, \mathrm{Tb}, \mathrm{Sb}, \mathrm{Kb}, \mathrm{Om}, \mathrm{Ok}, \mathrm{Ks}$, Lkoc $\mathrm{Al}, \mathrm{Ab}, \mathrm{N}, \mathrm{Ka}, \mathrm{St}, \mathrm{Ta}, \mathrm{Kl}, \mathrm{Tb}, \mathrm{Sb}, \mathrm{Kb}, \mathrm{Om}, \mathrm{Ok}$, Oba, Ks

$\mathrm{Al}, \mathrm{Ab}, \mathrm{N}, \mathrm{St}, \mathrm{Ta}, \mathrm{Oa}, \mathrm{Tb}, \mathrm{Sb}, \mathrm{Kb}, \mathrm{Om}, \mathrm{Ok}, \mathrm{Obb}, \mathrm{Ks}$, Lkoc, Lkor, Li

Al, Ab, N, St, Ta, Sa, Oa, Tb, Sb, Kb, Om, Ok, Oba, Obb,

Ks, Lkoc, Lkor, Le, Li

$\mathrm{Ab}, \mathrm{St}, \mathrm{Ta}, \mathrm{Tb}, \mathrm{Ok}, \mathrm{Oba}$

$\mathrm{Al}, \mathrm{Ab}, \mathrm{N}, \mathrm{Ka}, \mathrm{St}, \mathrm{Ta}, \mathrm{Oa}, \mathrm{Tb}, \mathrm{Sb}, \mathrm{Kb}, \mathrm{Om}, \mathrm{Ok}, \mathrm{Oba}, \mathrm{Obb}$,

Ks, Lkoc, Lkor, Le, Li

Ks, Lkoc, Lkor, Li

Ab, Lkoc, Le

$\mathrm{Al}, \mathrm{Ab}, \mathrm{N}, \mathrm{Ka}, \mathrm{St}, \mathrm{Ta}, \mathrm{KI}, \mathrm{Oa}, \mathrm{Tb}, \mathrm{Sb}, \mathrm{Kb}, \mathrm{Om}, \mathrm{Ok}, \mathrm{Obb}$,

Ks, Lkoc, Lkor, Le, Li

$\mathrm{Al}, \mathrm{Ab}, \mathrm{St}, \mathrm{Ta}, \mathrm{Sa}, \mathrm{Oa}, \mathrm{Tb}, \mathrm{Kb}, \mathrm{Om}, \mathrm{Ok}, \mathrm{Ks}$, Lkoc, Lkor

$\mathrm{Al}, \mathrm{Ab}, \mathrm{N}, \mathrm{St}, \mathrm{Ta}, \mathrm{KI}, \mathrm{Oa}, \mathrm{Tb}, \mathrm{Sb}, \mathrm{Kb}, \mathrm{Ok}, \mathrm{Oba}, \mathrm{Obb}, \mathrm{Ks}$,

Lkoc, Lkor, Le, Li

$\mathrm{Ab}, \mathrm{Ta}, \mathrm{Oa}, \mathrm{Sb}$

$\mathrm{Al}, \mathrm{Ab}, \mathrm{Ta}$

$\mathrm{Ab}, \mathrm{N}, \mathrm{Ta}, \mathrm{Kb}$

$\mathrm{Li}$

$\mathrm{Ab}, \mathrm{N}, \mathrm{St}, \mathrm{Ta}, \mathrm{Oa}, \mathrm{Tb}, \mathrm{Sb}, \mathrm{Ks}$

Le

$\mathrm{Al}, \mathrm{Ab}, \mathrm{N}, \mathrm{Ka}, \mathrm{St}, \mathrm{Ta}, \mathrm{Sa}, \mathrm{KI}, \mathrm{Oa}, \mathrm{Tb}, \mathrm{Sb}, \mathrm{Kb}, \mathrm{Om}, \mathrm{Ok}$,

$\mathrm{Al}, \mathrm{Ab}, \mathrm{N}, \mathrm{St}, \mathrm{Ta}, \mathrm{Sa}, \mathrm{Oa}, \mathrm{Tb}, \mathrm{Sb}, \mathrm{Kb}, \mathrm{Ok}, \mathrm{Oba}, \mathrm{Obb}, \mathrm{Ks}$, Lkoc, Li

$\mathrm{Al}, \mathrm{Ab}, \mathrm{N}, \mathrm{St}, \mathrm{Ta}, \mathrm{Sa}, \mathrm{Oa}, \mathrm{Tb}, \mathrm{Sb}, \mathrm{Kb}, \mathrm{Om}, \mathrm{Ok}, \mathrm{Oba}, \mathrm{Obb}$, Ks, Le, Li

$\mathrm{Ab}, \mathrm{N}, \mathrm{Ta}, \mathrm{Sa}, \mathrm{Tb}$

Ok, Oba

Ab, N, St, Ta, Sa, Oa, Tb, Sb, Kb, Oba, Obb, Ks, Lkoc,

Lkor, Le, Li

$\mathrm{Ab}, \mathrm{St}, \mathrm{Oa}, \mathrm{Tb}, \mathrm{Oba}, \mathrm{Obb}, \mathrm{Li}$

Oba, Obb, Ks, Lkoc, Lkor, Le, Li

$\mathrm{Al}, \mathrm{Ab}, \mathrm{N}, \mathrm{St}, \mathrm{Ta}, \mathrm{Kb}, \mathrm{Om}, \mathrm{Oba}$

$A b$

$\mathrm{Al}, \mathrm{Ab}, \mathrm{N}, \mathrm{Ka}$, St, Ta, Sa, KI, Oa, Tb, Sb, Kb, Om, Ok,

Oba, Obb, Le, Li

Le, Li

Ab, Ok, Oba, Lkoc 
S. (Trimicra) pilipes (Fabricius, 1787)

Tasiocera (Dasymolophilus) exigua Savchenko, 1973 Al, Ab, N, Ta, Sa, Tb, Sb, Kb, Ok, Ks

T. (D.) fuscescens (Lackschewitz, 1940)

T. (D.) murina (Meigen, 1818)

\section{Tipulidae}

Angarotipula tumidicornis (Lundström, 1907)

Ctenophora (C.) flaveolata (Fabricius, 1794)

C. (C.) guttata Meigen, 1818

C. (C.) nigriceps (Tjeder, 1949)

C. (C.) pectinicornis (Linnaeus, 1758)

Dictenidia bimaculata (Linnaeus, 1760)

Dolichopeza (D.) albipes (Ström, 1768)

D. (D.) bifida Oesterbrook \& Lantsov 2011

Nephrotoma aculeata (Loew, 1871)

N. analis (Schummel, 1833)

N. appendiculata (Pierre, 1919)

N. cornicina (Linnaeus, 1758)

N. crocata (Linnaeus, 1758)

N. dorsalis (Fabricius, 1781)

N. flavescens (Linnaeus, 1758)

N. lundbecki (Nielsen, 1907)

N. Iunulicornis (Schummel, 1833)

N. pratensis (Linnaeus, 1758)

N. quadristriata (Schummel, 1833)

N. relicta (Savchenko, 1973)

N. scurra (Meigen, 1818)

N. submaculosa Edwards, 1928

N. tenuipes (Riedel, 1910)

Nigrotipula nigra (Linnaeus, 1758)

Phoroctenia vittata (Meigen, 1830)

Prionocera abscondita Lackschewitz, 1933

P. chosenicola Alexander, 1945

P. pubescens Loew, 1844

$P$. recta Tjeder, 1948

$P$. ringdahli Tjeder, 1948

$P$. serricornis (Zetterstedt, 1838)

P. subserricornis (Zetterstedt, 1851)

P. turcica (Fabricius, 1787)

P. woodorum Brodo, 1987

Tanyptera (T.) atrata (Linnaeus, 1758)

T. (T.) nigricornis (Meigen, 1818)

Tipula (Acutipula) fulvipennis De Geer, 1776

T. (A.) maxima Poda, 1761

T. (Arctotipula) salicetorum Siebke, 1870

T. (Beringotipula) unca Wiedemann, 1817

T. (Dendrotipula) flavolineata Meigen, 1804

T. (Emodotipula) obscuriventris Strobl, 1900

T. (Lindnerina) bistilata Lundström, 1907

T. (L.) subexcisa Lundström, 1907

T. (Lunatipula) affinis Schummel, 1833

T. (L.) circumdata Siebke, 1863

T. (L.) fascipennis Meigen, 1818

T. (L.) humilis Staeger, 1840

T. (L.) laetabilis Zetterstedt, 1838

T. (L.) limitata Schummel, 1833
$\mathrm{Ab}, \mathrm{N}$

$\mathrm{Ab}, \mathrm{N}, \mathrm{Ta}, \mathrm{Ks}$

Sa, Oba, Obb, Lkoc, Lkor, Le, Li

$\mathrm{Ab}$

$\mathrm{Ab}, \mathrm{N}, \mathrm{Ka}, \mathrm{St}, \mathrm{Ta}, \mathrm{Sa}, \mathrm{Tb}, \mathrm{Sb}, \mathrm{Kb}, \mathrm{Om}, \mathrm{Ok}$

$\mathrm{Kb}$

$\mathrm{Al}, \mathrm{Ab}(?)^{2}$

$\mathrm{Al}, \mathrm{Ab}, \mathrm{N}, \mathrm{St}, \mathrm{Ta}, \mathrm{Sa}, \mathrm{Kl}, \mathrm{Oa}, \mathrm{Tb}, \mathrm{Sb}, \mathrm{Kb}, \mathrm{Om}, \mathrm{Ok}, \mathrm{Oba}$, Obb, Ks, Lkoc, Le, Li

$\mathrm{Al}, \mathrm{Ab}, \mathrm{N}, \mathrm{St}, \mathrm{Sa}, \mathrm{Oa}, \mathrm{Tb}, \mathrm{Sb}$

$\mathrm{Tb}, \mathrm{Kb}, \mathrm{Lkor}, \mathrm{Li}$

$\mathrm{Ab}, \mathrm{N}, \mathrm{Ka}, \mathrm{St}, \mathrm{Ta}, \mathrm{Sa}, \mathrm{Oa}, \mathrm{Tb}, \mathrm{Sb}, \mathrm{Kb}, \mathrm{Ok}$

$\mathrm{Al}, \mathrm{Ab}, \mathrm{N}, \mathrm{St}, \mathrm{Ta}, \mathrm{Oa}, \mathrm{Tb}, \mathrm{Sb}, \mathrm{Kb}, \mathrm{Oba}$

$\mathrm{Al}, \mathrm{Ab}, \mathrm{N}, \mathrm{Ka}, \mathrm{St}, \mathrm{Ta}, \mathrm{KI}, \mathrm{Tb}, \mathrm{Kb}$

$\mathrm{Al}, \mathrm{Ab}, \mathrm{N}, \mathrm{Ka}, \mathrm{Ta}, \mathrm{Sa}, \mathrm{Oa}, \mathrm{Tb}, \mathrm{Sb}, \mathrm{Kb}, \mathrm{Om}, \mathrm{Ok}, \mathrm{Oba}$

$\mathrm{Al}, \mathrm{Ab}, \mathrm{N}, \mathrm{St}, \mathrm{Ta}, \mathrm{Sa}, \mathrm{KI}, \mathrm{Oa}, \mathrm{Tb}, \mathrm{Sb}, \mathrm{Kb}, \mathrm{Om}$

$\mathrm{N}, \mathrm{Ka}, \mathrm{Ta}, \mathrm{KI}, \mathrm{Oa}, \mathrm{Kb}, \mathrm{Oba}, \mathrm{Obb}, \mathrm{Ks}$

$\mathrm{Al}, \mathrm{Ab}, \mathrm{N}, \mathrm{Ka}$, St, Ta, Sa, KI, Oa, Tb, Kb, Oba

Le

$\mathrm{Al}, \mathrm{Ab}, \mathrm{N}, \mathrm{Ka}, \mathrm{St}, \mathrm{Ta}, \mathrm{Sa}, \mathrm{KI}, \mathrm{Oa}, \mathrm{Tb}, \mathrm{Kb}, \mathrm{Oba}$

$\mathrm{Al}, \mathrm{N}, \mathrm{Ta}, \mathrm{Sa}, \mathrm{KI}, \mathrm{Tb}$

$\mathrm{Ab}, \mathrm{N}, \mathrm{Ka}, \mathrm{St}, \mathrm{Ta}, \mathrm{Sb}, \mathrm{Ks}$

Ks

$\mathrm{Al}, \mathrm{Ab}, \mathrm{N}, \mathrm{Ka}, \mathrm{St}, \mathrm{Ta}, \mathrm{Sa}, \mathrm{Kl}, \mathrm{Oa}, \mathrm{Tb}, \mathrm{Sb}, \mathrm{Kb}, \mathrm{Om}, \mathrm{Ok}$,

Oba, Obb, Ks, Lkoc, Lkor, Li

$\mathrm{Oa}$

$\mathrm{Ab}, \mathrm{N}, \mathrm{Ka}, \mathrm{St}, \mathrm{Ta}, \mathrm{Oa}, \mathrm{Tb}, \mathrm{Sb}, \mathrm{Kb}, \mathrm{Oba}, \mathrm{Ks}$, Lkoc

$\mathrm{Al}, \mathrm{Ab}, \mathrm{N}, \mathrm{Ka}, \mathrm{St}, \mathrm{Ta}, \mathrm{Kl}, \mathrm{Oa}, \mathrm{Tb}, \mathrm{Sb}, \mathrm{Kb}, \mathrm{Om}$, Oba, Le

$\mathrm{Tb}, \mathrm{Sb}, \mathrm{Oba}, \mathrm{Obb}, \mathrm{Ks}$, Le

Le, Li

$\mathrm{Ab}, \mathrm{N}, \mathrm{Ta}, \mathrm{Oa}, \mathrm{Tb}, \mathrm{Obb}, \mathrm{Ks}$, Lkoc, Lkor, Le, Li

$\mathrm{Al}, \mathrm{Ab}, \mathrm{Ta}, \mathrm{Oa}, \mathrm{Tb}, \mathrm{Sb}, \mathrm{Kb}, \mathrm{Om}, \mathrm{Ok}$, Oba, Obb, Ks, Lkoc,

Lkor, Le, Li

Ks, Lkoc, Le, Li

Oba, Ks, Lkoc, Lkor, Le, Li

Ta, Ks, Lkoc, Lkor, Le, Li

$\mathrm{Ab}, \mathrm{N}, \mathrm{Ka}, \mathrm{St}, \mathrm{Ta}, \mathrm{KI}, \mathrm{Oa}, \mathrm{Tb}, \mathrm{Sb}, \mathrm{Kb}, \mathrm{Om}, \mathrm{Ok}, \mathrm{Oba}, \mathrm{Obb}$, Ks, Lkoc, Lkor, Le, Li

$\mathrm{Al}, \mathrm{Ab}, \mathrm{N}, \mathrm{Ka}, \mathrm{St}, \mathrm{Ta}, \mathrm{Sa}, \mathrm{KI}, \mathrm{Oa}, \mathrm{Sb}, \mathrm{Kb}, \mathrm{Om}, \mathrm{Oba}, \mathrm{Obb}$, Ks, Lkoc, Lkor, Le, Li

Oba, Ks, Le, Li

$\mathrm{Al}, \mathrm{Ab}, \mathrm{N}, \mathrm{Ka}, \mathrm{St}, \mathrm{Ta}, \mathrm{Sa}, \mathrm{Oa}, \mathrm{Tb}, \mathrm{Sb}, \mathrm{Kb}, \mathrm{Om}, \mathrm{Ok}, \mathrm{Oba}$,

Ks, Lkoc, Lkor, Le, Li

Al, Ab, N, Ta, Oa, Tb, Kb, Ok, Oba, Obb, Ks, Lkoc, Le, Li

$\mathrm{Al}, \mathrm{Ab}, \mathrm{N}, \mathrm{Ka}, \mathrm{St}, \mathrm{Ta}, \mathrm{Sa}, \mathrm{Kl}, \mathrm{Oa}, \mathrm{Tb}, \mathrm{Sb}, \mathrm{Kb}, \mathrm{Oba}, \mathrm{Ks}$

$\mathrm{Al}, \mathrm{Ab}, \mathrm{N}, \mathrm{Sa}, \mathrm{Tb}$

Lkoc, Lkor, Le, Li

$\mathrm{Al}, \mathrm{Ab}, \mathrm{N}, \mathrm{Ka}, \mathrm{St}, \mathrm{Ta}, \mathrm{KI}, \mathrm{Oa}, \mathrm{Tb}, \mathrm{Sb}, \mathrm{Kb}, \mathrm{Om}, \mathrm{Ok}$, Oba,

Obb, Ks, Lkoc

$\mathrm{Ab}, \mathrm{N}, \mathrm{St}, \mathrm{Ta}, \mathrm{Tb}$

Ok, Ks, Le

$\mathrm{Ab}, \mathrm{N}, \mathrm{Sa}, \mathrm{Sb}, \mathrm{Oba}, \mathrm{Obb}, \mathrm{Lkoc}, \mathrm{Le}, \mathrm{Li}$

Ks, Lkoc, Lkor, Le, Li

$\mathrm{Al}, \mathrm{Ab}, \mathrm{N}, \mathrm{Ta}, \mathrm{Kl}, \mathrm{Sb}, \mathrm{Om}, \mathrm{Oba}, \mathrm{Obb}, \mathrm{Ks}$, Lkoc, Li

$\mathrm{Ab}, \mathrm{Ta}, \mathrm{Oa}, \mathrm{Tb}, \mathrm{Sb}, \mathrm{Kb}, \mathrm{Ok}, \mathrm{Obb}, \mathrm{Ks}$, Lkoc, Lkor, Le, Li

$\mathrm{Al}, \mathrm{Ab}, \mathrm{N}, \mathrm{Ka}$, St, Ta, Sa, KI, Oa, Tb, Sb, Kb, Om, Oba

$\mathrm{Ab}, \mathrm{N}, \mathrm{Ka}, \mathrm{St}, \mathrm{KI}, \mathrm{Oa}, \mathrm{Om}, \mathrm{Oba}$, Li

$\mathrm{Al}, \mathrm{Ab}, \mathrm{N}, \mathrm{Ka}, \mathrm{St}, \mathrm{Ta}, \mathrm{Oa}, \mathrm{Sb}, \mathrm{Om}, \mathrm{Oba}, \mathrm{Obb}$, Lkoc

$\mathrm{Ab}, \mathrm{N}, \mathrm{St}, \mathrm{Ta}, \mathrm{Sa}, \mathrm{Oa}, \mathrm{Tb}, \mathrm{Sb}, \mathrm{Kb}, \mathrm{Ok}, \mathrm{Oba}, \mathrm{Obb}, \mathrm{Ks}$, 


\section{T. (L.) Iunata Linnaeus, 1758}

T. (L.) recticornis Schummel, 1833

T. (L.) selene Meigen, 1830

T. (L.) trispinosa Lundström, 1907

T. (L.) vernalis Meigen, 1804

T. (Odonatisca) nodicornis Meigen, 1818

T. (Platytipula) luteipennis Meigen, 1830

T. (P.) melanoceros Schummel, 1833

T. (Pterelachisus) cinereocincta Lundström, 1907

T. (P.) crassicornis Zetterstedt, 1838

T. $(P$.$) irrorata Macquart, 1826$

T. (P.) jutlandica Nielsen, 1947

T. (P.) kaisilai Mannheims, 1954

T. (P.) laetibasis Alexander, 1934

T. (P.) luridorostris Schummel, 1833

T. (P.) matsumuriana pseudohortensis Lackschewitz, 1932

T. (P.) mutila Wahlgren, 1905

T. (P.) octomaculata Savchenko, 1964

T. (P.) pabulina Meigen, 1818

T. (P.) pseudoirrorata Goetghebuer, 1921

T. (P.) stenostyla Savchenko, 1964

T. (P.) submarmorata Schummel, 1833

T. (P.) truncorum Meigen, 1830

T. $(P$.$) varipennis Meigen, 1818$

T. (P.) wahlgreni Lackschewitz, 1925

T. (P.) winthemi Lackschewitz, 1932

T. (Savtshenkia) alpium Bergroth, 1888

T. (S.) benesignata Mannheims, 1954

T. (S.) confusa van der Wulp, 1883

T. (S.) gimmerthali Lackschewitz, 1925

T. (S.) grisescens Zetterstedt, 1851

T. (S.) interserta Riedel, 1913

T. (S.) invenusta Riedel, 1919

T. (S.) limbata Zetterstedt, 1838

T. (S.) obsoleta Meigen, 1818

T. (S.) pagana Meigen, 1818

T. (S.) signata Staeger, 1840

T. (S.) subnodicornis Zetterstedt, 1838

T. (Schummelia) variicornis Schummel, 1833

T. (Tipula) paludosa Meigen, 1830

T. (T.) subcunctans Alexander, 1921

T. (Vestiplex) excisa Schummel, 1833

T. (V.) hortorum Linnaeus, 1758

T. (V.) laccata Lundstrom \& Frey, 1916

$T$. (V.) montana verberneae

Mannheims \& Theowald, 1959

T. (V.) nubeculosa Meigen, 1804

T. (V.) pallidicosta Pierre, 1924
Lkoc, Lkor, Li

Al, Ab, N, Ka, St, Ta, Sa, Kl, Oa, Tb, Sb, Kb, Ks, Lkoc, Le, $\mathrm{Li}$

$\mathrm{Ab}, \mathrm{Tb}$

$\mathrm{Al}, \mathrm{Ab}, \mathrm{N}, \mathrm{St}, \mathrm{Ta}, \mathrm{Oa}, \mathrm{Tb}, \mathrm{Kb}, \mathrm{Oba}$

Oba, Ks, Lkoc, Le, Li

$\mathrm{Al}, \mathrm{Ab}, \mathrm{N}, \mathrm{Ka}, \mathrm{Ta}, \mathrm{Sa}, \mathrm{Oa}, \mathrm{Kb}, \mathrm{Oba}, \mathrm{Li}$

$\mathrm{Ab}, \mathrm{N}, \mathrm{Ta}, \mathrm{Sa}, \mathrm{Sb}, \mathrm{Kb}, \mathrm{Ks}$, Lkoc, Le, Li

$\mathrm{Al}, \mathrm{Ab}, \mathrm{N}, \mathrm{Ka}, \mathrm{St}, \mathrm{Ta}, \mathrm{KI}, \mathrm{Oa}, \mathrm{Tb}, \mathrm{Kb}, \mathrm{Om}, \mathrm{Ok}, \mathrm{Oba}, \mathrm{Obb}$, Ks, Lkoc, Lkor, Le

$\mathrm{Al}, \mathrm{Ab}, \mathrm{N}, \mathrm{Ka}, \mathrm{St}, \mathrm{Ta}, \mathrm{Oa}, \mathrm{Tb}, \mathrm{Sb}, \mathrm{Kb}, \mathrm{Ok}, \mathrm{Oba}, \mathrm{Obb}, \mathrm{Ks}$, Lkoc, Lkor, Le, Li

$\mathrm{Ab}, \mathrm{Ta}, \mathrm{Sb}, \mathrm{Ks}$

$\mathrm{Kb}, \mathrm{Li}$

$\mathrm{Al}, \mathrm{Ab}, \mathrm{N}, \mathrm{Ka}, \mathrm{St}, \mathrm{Ta}, \mathrm{Sa}, \mathrm{KI}, \mathrm{Oa}, \mathrm{Tb}, \mathrm{Sb}, \mathrm{Kb}, \mathrm{Om}, \mathrm{Ok}$, Obb, Ks, Lkoc

$\mathrm{Kl}$

Lkoc

$\mathrm{N}, \mathrm{Tb}, \mathrm{Lkoc}$

$\mathrm{Ab}, \mathrm{St}, \mathrm{Ks}, \mathrm{Lkoc}$

$\mathrm{N}, \mathrm{Ta}, \mathrm{Tb}$

Ab, St, Ta, Oa, Tb, Sb, Kb, Ok, Oba, Ks, Lkoc, Le, Li $\mathrm{Kb}, \mathrm{Ks}$

$\mathrm{N}$

$\mathrm{Ta}, \mathrm{Kb}, \mathrm{Ks}$, Lkoc, Lkor

$\mathrm{N}, \mathrm{Ta}, \mathrm{Sb}, \mathrm{Lkoc}$

$\mathrm{Al}, \mathrm{Ab}, \mathrm{N}, \mathrm{Ka}, \mathrm{St}, \mathrm{Ta}, \mathrm{Sa}, \mathrm{KI}, \mathrm{Oa}, \mathrm{Tb}, \mathrm{Sb}, \mathrm{Kb}, \mathrm{Om}, \mathrm{Ok}$, Oba, Ks, Le

$\mathrm{Ab}, \mathrm{N}, \mathrm{Ka}, \mathrm{Ta}, \mathrm{Sa}, \mathrm{Oa}, \mathrm{Tb}, \mathrm{Kb}, \mathrm{Ok}, \mathrm{Oba}, \mathrm{Ks}$, Lkoc, Le, Li $\mathrm{Al}, \mathrm{Ab}, \mathrm{N}, \mathrm{Ka}$, St, Ta, Sa, KI, Oa, Tb, Sb, Kb, Om, Ok,

Oba, Obb, Ks, Lkoc, Lkor, Le, Li

$\mathrm{Ta}, \mathrm{Oa}, \mathrm{Tb}, \mathrm{Sb}, \mathrm{Kb}, \mathrm{Ok}, \mathrm{Ks}$

$\mathrm{Ab}, \mathrm{N}, \mathrm{Ka}, \mathrm{Ta}, \mathrm{Sa}, \mathrm{Tb}, \mathrm{Ok}, \mathrm{Ks}$

$\mathrm{Ab}, \mathrm{N}$

$\mathrm{Ta}, \mathrm{Kb}, \mathrm{Ok}, \mathrm{Oba}, \mathrm{Ks}$, Li

$\mathrm{Al}, \mathrm{Ab}, \mathrm{N}, \mathrm{Ka}, \mathrm{Ta}, \mathrm{Oa}$

Obb, Ks, Lkoc, Lkor, Le, Li

$\mathrm{Ab}, \mathrm{N}, \mathrm{St}, \mathrm{Ta}, \mathrm{Sa}, \mathrm{Oa}, \mathrm{Tb}, \mathrm{Sb}, \mathrm{Kb}, \mathrm{Ok}, \mathrm{Oba}, \mathrm{Obb}, \mathrm{Ks}$, Lkoc, Lkor, Le, Li

$\mathrm{Al}, \mathrm{Ab}, \mathrm{Ta}, \mathrm{Oa}, \mathrm{Tb}, \mathrm{Sb}, \mathrm{Om}, \mathrm{Oba}, \mathrm{Obb}, \mathrm{Ks}$, Lkoc

Lkoc, Lkor, Le, Li

$\mathrm{Ab}, \mathrm{N}, \mathrm{Ta}, \mathrm{Oa}, \mathrm{Tb}, \mathrm{Sb}, \mathrm{Kb}, \mathrm{Ok}$, Oba, Obb, Ks, Lkoc, Lkor, Le, Li

$\mathrm{Al}, \mathrm{Ab}, \mathrm{Ta}, \mathrm{Sa}, \mathrm{Lkoc}, \mathrm{Li}$

$\mathrm{Al}, \mathrm{Ab}, \mathrm{N}, \mathrm{Ka}, \mathrm{Ta}, \mathrm{Oa}, \mathrm{Tb}, \mathrm{Sb}, \mathrm{Ks}$

$\mathrm{Al}, \mathrm{Ab}, \mathrm{N}, \mathrm{Ta}, \mathrm{Oa}, \mathrm{Tb}, \mathrm{Sb}, \mathrm{Kb}, \mathrm{Oba}, \mathrm{Li}$

$\mathrm{Al}, \mathrm{Ab}, \mathrm{N}, \mathrm{St}, \mathrm{Ta}, \mathrm{Oa}, \mathrm{Tb}, \mathrm{Sb}, \mathrm{Kb}, \mathrm{Om}, \mathrm{Ok}, \mathrm{Oba}, \mathrm{Obb}, \mathrm{Ks}$, Lkoc, Lkor, Le, Li

$\mathrm{Ab}, \mathrm{N}, \mathrm{Ka}, \mathrm{St}, \mathrm{Ta}, \mathrm{Sa}, \mathrm{Kl}, \mathrm{Oa}, \mathrm{Tb}, \mathrm{Sb}, \mathrm{Kb}, \mathrm{Om}, \mathrm{Ok}, \mathrm{Oba}$, Obb, Ks, Lkoc, Le, Li

$\mathrm{Al}, \mathrm{Ab}, \mathrm{N}, \mathrm{Ka}$, St, Ta, Sa, KI, Oa, Tb, Sb, Kb, Oba

$\mathrm{Al}, \mathrm{Ab}, \mathrm{N}, \mathrm{Ka}$, St, Ta, Sa, Oa, Sb, Oba, Obb, Lkor

$\mathrm{Oa}(\text { ? })^{3}$, Oba, Obb, Ks, Lkoc, Lkor, Le, Li

Al, Ab, N, Ta

Ks, Lkoc, Le, Li

Ks, Lkoc, Le, Li

Ab, N, Ka, St, Ta, Sa, Oa, Tb, Sb, Kb, Ok, Oba, Obb, Ks, Lkoc, Lkor, Le, Li

Oba, Obb, Lkoc, Le 
T. (V.) scripta Meigen, 1830

T. (V.) sintenisi Lackschewitz, 1933

T. (V.) tchukchi Alexander, 1934

T. (Yamatotipula) chonsaniana Alexander, 1945

T. (Y.) coerulescens Lackschewitz, 1923

T. (Y.) couckei Tonnoir, 1921

T. (Y.) fendleri Mannheims, 1963

T. (Y.) freyana Lackschewitz, 1936

T. (Y.) lateralis Meigen, 1804

T. (Y.) marginella Theowald, 1980

T. (Y.) moesta Riedel, 1919

T. (Y.) montium Egger, 1863

T. (Y.) pierrei Tonnoir, 1921

T. (Y.) pruinosa Wiedemann, 1817

T. (Y.) quadrivittata Staeger, 1840

\section{Pediciidae}

Dicranota (D.) bimaculata (Schummel, 1829)

D. (D.) crassicauda Tjeder, 1972

D. (D.) guerini Zetterstedt, 1838

D. (Paradicranota) gracilipes Wahlgren, 1905

D. (P.) pavida (Haliday, 1833)

D. (P.) robusta Lundström, 1912

D. $(P$.$) subtilis Loew, 1871$

D. (Rhaphidolabis) exclusa (Walker, 1848)

Pedicia (Crunobia) straminea (Meigen, 1838)

$P$. (P.) rivosa (Linnaeus, 1758)

Tricyphona (T.) immaculata (Meigen, 1804)

T. (T.) livida Madarassy, 1881

T. (T.) schummeli Edwards, 1921

T. (T.) unicolor (Schummel, 1829)

Ula (U.) bolitophila Loew, 1869

U. (U.) kiushiuensis Alexander, 1933

U. (U.) mixta Starý, 1983

U. (U.) mollissima Haliday, 1833

U. (U.) sylvatica (Meigen, 1818)

\section{Cylindrotomidae}

Cylindrotoma borealis Peus, 1952

C. distinctissima (Meigen, 1818)

C. nigriventris Loew, 1849

Diogma caudata Takahashi, 1960

D. glabrata (Meigen, 1818)

Phalacrocera replicata (Linnaeus, 1758)

Triogma trisulcata (Schummel, 1829)
$\mathrm{Al}, \mathrm{Ab}, \mathrm{N}, \mathrm{Ka}, \mathrm{St}, \mathrm{Ta}, \mathrm{Sa}, \mathrm{KI}, \mathrm{Oa}, \mathrm{Tb}, \mathrm{Sb}, \mathrm{Kb}, \mathrm{Om}, \mathrm{Ok}$,

Oba, Obb, Ks, Lkoc, Le

$\mathrm{St}, \mathrm{Oa}, \mathrm{Tb}, \mathrm{Sb}, \mathrm{Kb}, \mathrm{Oba}, \mathrm{Obb}, \mathrm{Ks}$, Lkoc, Li

$\mathrm{Le}, \mathrm{Li}$

$\mathrm{Oa}, \mathrm{Oba}, \mathrm{Ks}$

$\mathrm{Al}, \mathrm{Ab}, \mathrm{N}, \mathrm{Ta}, \mathrm{Oa}, \mathrm{Sb}, \mathrm{Kb}, \mathrm{Ok}, \mathrm{Oba}, \mathrm{Obb}, \mathrm{Ks}$, Lkoc, Li

$\mathrm{Ab}, \mathrm{N}, \mathrm{St}, \mathrm{Ta}, \mathrm{Sb}, \mathrm{Ok}, \mathrm{Ks}$, Lkor, Le, Li

$\mathrm{Ks}$, Lkoc, Le, Li

$\mathrm{Kb}, \mathrm{Ks}$, Lkoc, Le

$\mathrm{Al}, \mathrm{Ab}, \mathrm{N}, \mathrm{Ka}, \mathrm{St}, \mathrm{Ta}, \mathrm{Kl}, \mathrm{Oa}, \mathrm{Kb}, \mathrm{Om}$, Oba, Ks, Le, Li

$\mathrm{Al}, \mathrm{Ab}, \mathrm{St}, \mathrm{Ta}, \mathrm{Kl}, \mathrm{Sb}, \mathrm{Kb}$

Lkoc, Le, Li

$\mathrm{Ab}, \mathrm{N}, \mathrm{Ta}, \mathrm{Tb}, \mathrm{Sb}, \mathrm{Kb}, \mathrm{Ks}$, Lkor, Le

$\mathrm{Ab}, \mathrm{N}, \mathrm{Ka}, \mathrm{St}, \mathrm{Ta}, \mathrm{Sa}, \mathrm{Kl}, \mathrm{Oa}, \mathrm{Tb}, \mathrm{Sb}, \mathrm{Om}, \mathrm{Oba}, \mathrm{Obb}, \mathrm{Ks}$

$\mathrm{Al}, \mathrm{Ab}, \mathrm{N}, \mathrm{Ka}, \mathrm{St}, \mathrm{Ta}, \mathrm{KI}, \mathrm{Oa}, \mathrm{Tb}, \mathrm{Sb}, \mathrm{Kb}, \mathrm{Om}, \mathrm{Ok}, \mathrm{Oba}, \mathrm{Ks}$ $\mathrm{Ab}, \mathrm{Ka}, \mathrm{Ta}, \mathrm{Tb}, \mathrm{Kb}, \mathrm{Om}$, Oba, Lkoc, Li

Ab, N, St, Ta, Oa, Tb, Kb, Ok, Oba, Obb, Ks, Lkoc, Lkor, Le, Li

Le

Ab, St, Ta, Sa, Oa, Tb, Sb, Kb, Ok, Oba, Obb, Ks, Lkoc, Lkor, Le, Li

$\mathrm{Ab}, \mathrm{Ta}, \mathrm{Tb}, \mathrm{Sb}, \mathrm{Ok}, \mathrm{Oba}, \mathrm{Ks}$, Lkoc, Lkor, Le, Li

$\mathrm{Ab}, \mathrm{N}, \mathrm{St}, \mathrm{Ta}, \mathrm{Sa}, \mathrm{Oa}, \mathrm{Tb}, \mathrm{Sb}, \mathrm{Kb}, \mathrm{Ok}, \mathrm{Oba}, \mathrm{Obb}, \mathrm{Ks}$

Lkoc, Lkor, Le, Li

Ks, Lkoc, Lkor, Le

Lkoc, Le, Li

$\mathrm{Ab}, \mathrm{N}, \mathrm{St}, \mathrm{Ta}, \mathrm{Sa}, \mathrm{Oa}, \mathrm{Tb}, \mathrm{Sb}, \mathrm{Kb}, \mathrm{Ok}, \mathrm{Oba}, \mathrm{Obb}, \mathrm{Ks}$, Lkoc, Lkor, Le, Li

$\mathrm{Ab}, \mathrm{N}, \mathrm{St}, \mathrm{Ta}, \mathrm{Sa}, \mathrm{Oa}, \mathrm{Tb}, \mathrm{Sb}, \mathrm{Kb}, \mathrm{Ok}, \mathrm{Oba}, \mathrm{Obb}, \mathrm{Ks}$

$\mathrm{Al}, \mathrm{Ab}, \mathrm{N}, \mathrm{Ka}$, St, Ta, Sa, Kl, Oa, Tb, Sb, Kb, Om, Ok,

Oba, Obb, Ks, Lkoc, Lkor, Le, Li

$\mathrm{Al}, \mathrm{Ab}, \mathrm{N}, \mathrm{St}, \mathrm{Ta}, \mathrm{Sa}, \mathrm{KI}, \mathrm{Oa}, \mathrm{Tb}, \mathrm{Sb}, \mathrm{Kb}, \mathrm{Om}, \mathrm{Ok}, \mathrm{Oba}$, Obb, Ks, Lkoc, Lkor, Le, Li

$\mathrm{Ab}, \mathrm{N}, \mathrm{St}, \mathrm{Ta}, \mathrm{Sa}, \mathrm{Oa}, \mathrm{Tb}, \mathrm{Sb}, \mathrm{Kb}, \mathrm{Ok}, \mathrm{Oba}, \mathrm{Obb}, \mathrm{Ks}$ $\mathrm{Al}, \mathrm{Ab}, \mathrm{N}, \mathrm{Ka}, \mathrm{St}, \mathrm{Ta}, \mathrm{Sa}, \mathrm{Oa}, \mathrm{Tb}, \mathrm{Kb}, \mathrm{Ok}, \mathrm{Oba}, \mathrm{Obb}, \mathrm{Ks}$, Lkoc, Le, Li

$\mathrm{Al}, \mathrm{Ab}, \mathrm{N}, \mathrm{Ka}, \mathrm{St}, \mathrm{Ta}, \mathrm{Sa}, \mathrm{Oa}, \mathrm{Tb}, \mathrm{Sb}, \mathrm{Kb}, \mathrm{Om}, \mathrm{Ok}, \mathrm{Oba}$, Obb, Ks, Lkoc, Lkor

$\mathrm{Ab}, \mathrm{N}, \mathrm{St}, \mathrm{Ta}, \mathrm{Sa}, \mathrm{Oa}, \mathrm{Tb}, \mathrm{Sb}, \mathrm{Kb}, \mathrm{Obb}, \mathrm{Lkoc}$

$\mathrm{N}, \mathrm{Ta}, \mathrm{Tb}, \mathrm{Sb}, \mathrm{Kb}, \mathrm{Ok}$, Obb, Ks, Lkoc

$\mathrm{Ab}, \mathrm{N}, \mathrm{Ka}, \mathrm{St}, \mathrm{Ta}, \mathrm{Sa}, \mathrm{KI}, \mathrm{Oa}, \mathrm{Tb}, \mathrm{Sb}, \mathrm{Kb}, \mathrm{Ok}, \mathrm{Oba}, \mathrm{Obb}$, Ks, Lkoc, Li

$\mathrm{Ab}, \mathrm{N}, \mathrm{Ta}, \mathrm{Oa}, \mathrm{Kb}, \mathrm{Ks}$, Lkoc

$\mathrm{Ab}, \mathrm{N}, \mathrm{Ka}, \mathrm{St}, \mathrm{Ta}, \mathrm{Sa}, \mathrm{Oa}, \mathrm{Tb}, \mathrm{Sb}, \mathrm{Kb}, \mathrm{Om}, \mathrm{Ok}, \mathrm{Oba}, \mathrm{Obb}$, Ks, Lkoc, Lkor, Le, Li

$\mathrm{Ab}, \mathrm{St}, \mathrm{Ta}, \mathrm{Oa}, \mathrm{Tb}$

$\mathrm{Al}, \mathrm{Ab}, \mathrm{St}, \mathrm{Ta}, \mathrm{KI}, \mathrm{Oa}, \mathrm{Tb}, \mathrm{Sb}, \mathrm{Kb}, \mathrm{Ok}, \mathrm{Oba}, \mathrm{Obb}, \mathrm{Ks}$, Lkoc, Lkor, Le, Li

$\mathrm{Ab}, \mathrm{N}, \mathrm{St}, \mathrm{Ta}, \mathrm{Sb}, \mathrm{Kb}$

$\mathrm{Oa}, \mathrm{Tb}, \mathrm{Sb}, \mathrm{Kb}, \mathrm{Ok}$, Oba, Obb, Ks, Lkoc, Lkor

$\mathrm{Al}, \mathrm{Ab}, \mathrm{N}, \mathrm{St}, \mathrm{Ta}, \mathrm{Sa}, \mathrm{Oa}, \mathrm{Tb}, \mathrm{Sb}, \mathrm{Kb}, \mathrm{Om}, \mathrm{Ok}, \mathrm{Ks}$

$\mathrm{Al}, \mathrm{Ab}, \mathrm{Ka}, \mathrm{St}, \mathrm{Ta}, \mathrm{Sa}, \mathrm{Oa}, \mathrm{Tb}, \mathrm{Sb}, \mathrm{Kb}, \mathrm{Om}, \mathrm{Ok}, \mathrm{Oba}, \mathrm{Obb}$,

Ks, Lkoc, Lkor, Le, Li

$\mathrm{Ab}, \mathrm{N}, \mathrm{St}, \mathrm{Ta}, \mathrm{Tb}, \mathrm{Sb}, \mathrm{Oba}, \mathrm{Lkoc}$

1) The female specimen was not recovered from the $\mathrm{MZH}$ collection and the identification could not be verified.

2) The record from $A b$ is uncertain, see Ctenophora pectinicornis in the main text.

3) The record from Oa (Mannheims 1954) is outside the main range of the species; specimen is not re-examined. 